BEATA STUDZIŻBA

\title{
POLICHROMIA SKARBCA KATEDRY WAWELSKIEJ JÓZEFA MEHOFFERA 1900-1902 ${ }^{1}$
}

Przedmiotem niniejszego artykułu jest projekt polichromii skarbca katedry na Wawelu autorstwa Józefa Mehoffera, z lat 1901-1902. Został on zrealizowany tylko częściowo. Jako jedno z najwybitniejszych dzieł sztuki Młodej Polski zasługuje na przypomnienie i dokładniejszą analizę.

Należy zauważyć, iż wiele mehofferowskich projektów polichromii (czy też mozaik) pod względem rangi artystycznej jest równorzędnych $\mathrm{z}$ dokonaniami artysty w dziedzinie witrażu. Fakt ten nie zostal do tej pory praktycznie dostrzeżony, gdyż większości monumentalnych koncepcji z zakresu dekoracji malarskiej Mehofferowi nie udało się zrealizować; niektóre zostały wykonane tylko fragmentarycznie. Najwybitniejsze z nich to projekty: polichromii skarbca katedry na Wawelu (1900-1902), polichromii katedry płockiej (1901), dekoracji malarskiej katedry ormiańskiej we Lwowie (1907-1913). Należą one do dojrzałego okresu twórczości artysty, który zamyka się w latach 1900-1913². Projekt poli-

${ }^{1}$ Artykuł napisany w oparciu o pracę magisterską autorki pt. Malarskie dekoracje ścienne Józefa Mehoffera z lat 1889-1913: z wczesnego i dojrzatego okresu twórczości; promotor: prof. Piotr Krakowski, Instytut Historii Sztuki UJ, 1990;

${ }^{2} \mathrm{~W}$ omawianej dziedzinie twórczości Mehoffera na podstawie analizy ikonograficznej stylistycznej można wyróżnić trzy fazy:

a) wczesną - od roku 1889 (kiedy to Mehoffer, jako uczeń Matejki, wziął wraz z Wyspiańskim udział w pracach przy realizacji matejkowskiej polichromii kościoła Mariackiego w Krakowic) do 1898. W tym czasie powstały następujące, nie zrealizowane projekty:

- projekt konkursowy dekoracji Rudolfmum w Pradze, 1891,

- projekty polichromii do triforiów mariackich, 1892-1896 (szkicowy, malarski projekt polichromii triforiów, zapewne z roku 1895, prezentowany był na wystawie Józef Mehoffer. Opus Magnum. Muzeum Narodowe w Krakowie, I-IV 2000),

- projekty polichromii kościoła Franciszkanów w Krakowie, 1894 (zachowane szkice)

b) fazę kształtowania się dojrzałego stylu, 1898-1900; Mehoffer wykonal wówczas projekt plafonu do pałacu Götza w Okocimiu (1898) oraz projekt fryzu na gmach TPSP w Krakowie (projekty konkursowe: 1899-1900); obydwu dzieł nie zrealizował;

c) w dojrzałym okresie twórczości (1900-1913) powstały:

- projekt polichromii kaplicy królowej Zofii w katedrze wawelskiej, 1900 (nie zrealizowany, zaginiony);

- projekt polichromii skarbca katedry na Wawelu, 1900-1902 (zrealizowany częśsiowo); 
chromii skarbca katedry wawelskiej otwiera najbardziej twórczą fazę artystycznych dokonań Mehoffera w dziedzinie dekoracji malarskiej.

W roku 1901 opublikowano broszurę Stanisława Tomkowicza Katedra i jej obecna restauracja, która przyczyniła się do tego, iż prace nad polichromią skarbca powierzono ostatecznie Józefowi Mehofferowi ${ }^{3}$. Autor broszury postawił zarzut restauratorom katedry wawelskiej, że roboty w niej zleca się cudzoziemcom, przy równoczesnym lekceważeniu talentów rodzimych, takich właśnie jak Mehoffer, znany już i ceniony zagranicą twórca witraży fryburskich. Zwierzchnictwo nad katedra $\mathrm{i}$ zarząd prowadzonych prac konserwatorskich sprawował wówczas kardynał Jan Puzyna, często krytykowany za swoje kontrowersyjne poczynania w tym zakresie. Miał on ponoć żałować później decyzji o zleceniu dekoracji skarbca Mehofferowi ${ }^{4}$.

Prace nad ozdobieniem skarbca artysta rozpoczał od wykonania malowideł na sklepieniu, którego to zadania podjął się w marcu roku $1901^{5}$. Tworzył równolegle projekty rozmaitych partii dekoracji. Ważnym źródłem informacji o przebiegu prac nad polichromia jest korespondencja Józefa Mehoffera do żony $^{6}$. I tak, w liście z 26.06.1901 artysta opisuje jeden z projektów geniuszy przedstawień figuralnych $w$ dolnych partiach sklepienia; w tejże kompozycji wy-

- projekt polichromii katedry płockiej, 1901 (nie zrealizowany); pracę nad projektami Mehoffer kontynuowal do maja 1903;

- polichromia kaplicy Szafrańców w katedrze na Wawelu, 1905-1906;

- dekoracja malarska sali posiedzeń gmachu Izby Przemysłowo-Handlowej w Krakowie, 1906;

- projekt fryzu do gmachu parlamentu w Wiedniu, 1906 (nie zrealizowany, zachowane szkice);

- projekt polichromii kaplicy Jana III Sobieskiego na Kahlenbergu (nie zrealizowany); artysta zajmował się sprawą tej dekoracji w latach 1911-1914, a nawet jeszcze po roku 1920;

- projekt dekoracji malarskiej katedry ormiańskiej we Lwowie, 1907-1913, którego jedyną zrealizowaną partia jest mozaika z wizerunkiem Trójcy Świętej w kopule. Jest to ostatnie z prekursorskich, wybitnych dzieł Mehoffera w zakresie dekoracji malarskiej. Projekty dekoracji malarskich późnej fazy twórczości (po roku 1913), chociaż przeważnie zrealizowane, nie dorównują pod względem rangi artystycznej jego wcześniejszym dokonaniom (szczególnie z lat 1898-1913) w tej dziedzinie.

${ }^{3}$ A. Zeńczak i J. Wapiennik-Kossowicz, opierając się na zachowanych listach do Mehoffera - S. Odrzywolskiego (z 4. 07. 1900) i J. Puzyny (z 26. 10. 1900) - wskazuja iż propozycję wykonania polichromii skarbca przedstawiono Mehofferowi w roku 1900. Zob.: Józef Mehoffer. Opus Magnum. Muzeum Narodowe w Krakowie 2000, s.28, 48, 158.

${ }_{4}$ "wyrzucał sobie kardynał zbytnią ustępliwość w oddaniu dekoracji skarbca młodemu Mehofferowi, wskutek 'niewczesnej reklamy' niedość mu powolnego Tomkowicza”. Cyt. wg: Biblioteka Zakładu Narodowego im. Ossolińskich we Wrocławiu [dalej: Ossol.]: rękopis J. J a n a kowskiej-M ehofferowej, Rozwój myśli twórczej Józefa Mehoffera, sygn. rkps nr 14039/II [dalej: Rozwój myśli...]. Rękopis ten to podstawowe źródło informacji dotyczących prac przy polichromii skarbca.

${ }^{5}$ Tamże. Źródłowe informacje w dokumentach Archiwum Kapituły Katedralnej Krakowskiej na Wawelu; w Księdze zaliczek I, pod hasłem „Józef Mehoffer", zamieszczono następującą wzmiankę: „Malowanie Skarbca. Deklaracja z 8.03.1901. Podjął się pomalowania sklepienia za cenę ryczałtową $7000 \mathrm{~K}$. Dodatek za pomalowanie woskowe, w myśl tejże samej oferty $-500 \mathrm{~K}$. Razem $7500 \mathrm{~K}$ ”, poniżej zaś zanotowano: „Deklaracją z dn. (brak daty ) podjałł się pomalowania ścian skarbca, za cenę ryczałtową $6000 \mathrm{~K}$. Razem 13500 K". W Księdze zaliczek II powtórzono informację o ofercie z 8.03, 1901.

${ }^{6}$ Głównie listy artysty do żony do Alwerni. [w:] Ossol., rkps nr 14039/II: Rozwój myśli..... 
obraził uskrzydlone, znaczone płomieniami na czołach postacie, $\mathrm{z}$ których jedna ma twarz Mickiewicza „wedle (...) maski z Montmorency”; z łatwością możemy stwierdzić, że projekt ten, to „Geniusze III" (fot. 3d) ${ }^{7}$. Z listów artysty do żony wiadomo, iż sklepienie malowano już na przełomie czerwca i lipca roku $1901^{\sigma}$. Wykonanie niebieskiego tła powierzono malarzowi-dekoratorowi Tuchowi, który wskutek interwencji Mehoffera musiał rozjaśnić pierwotnie zastosowany kolor. Jeszcze w czerwcu 1901 przystapiono do malowania żeber i wykonania stiukowego ornamentu w kształcie korony, który stanowi oprawę dla kompozycji geniuszy?.

Należy podkreślić, że Mehoffer dążył do jak najdoskonalszej realizacji swoich idei kompozycyjnych. Uczestniczył sam w pracach wykonawczych i przywiązywał ogromną wage do starannego opracowania detali, niejednokrotnie ingerując $\mathrm{w}$ ich wykończenie. Tak też było w przypadku polichromii skarbca, o czym świadczy np. fragment listu z 2 lipca 1901: „Dzisiaj znowu całe popołudnie medytowałem nad żebrami, które się malują i które rzeczywiście dobre nie były. Utrudnienie jest wielkie, z powodu załamywania się wzoru na profilu żebra. Poprawiałem sam z największą uwagą i skupieniem, dopóty, dopóki nie zaczęło być lepiej" $"$. W tym czasie artysta pracował również nad akwarelowym projektem fryzu aniołków na sklepienie, dbając o to, by nie przypominały one aniołów matejkowskich ${ }^{11}$. Realizacje projektu zlecono malarzowi Taladze.

Po wykonaniu polichromii jednego przęsła sklepienia, 10 lipca 1901, odbyła się komisja z udziałem kardynała Puzyny. Mehoffer przeprowadził wcześniej rozmowe z Tomkowiczem i Odrzywolskim oraz zaprosił do skarbca innych członków komitetu, ,żeby sobie każdy sąd wyrobił”'12. Wiadomo, iż zyskał pochwałe Mariana Sokołowskiego ${ }^{13}$.

10 lipca przystapił do realizacji pierwszej z grup geniuszy ${ }^{14}$. Trwają równocześnie prace nad polichromią centralnej partii sklepienia; ukończono ją w poło-

\footnotetext{
${ }^{7}$ Muzeum Mazowieckie w Płocku [dalej: Muz. Maz.] - Depozyt nr 501.

${ }^{8}$ Zob. też Kronika krakowska z roku Pańskiego 1901 [dalej: Kronika 1901] w Kalendarzu Krakowskim Józefa Czecha na rok 1902 [dalej: Kalendarz 1902], s. 75.

${ }^{9}$ Listy Mehoffera do żony z 2. 07. 1901 i 28. 06. 1901. Ossol., rkps nr 14039/1I: Rozwój mysli....

${ }^{10}$ Tamże.

${ }^{11}$ W liście z 28. 06. 1901 czytamy: „Do wczoraj kończyłem z zaparciem te dwie pierwsze pary główek (aniołków), starając się uniknąć w obrobieniu charakteru matejkowskiego, w który łatwo się wpada, ponieważ to akwarela". - Ossol., rkps nr 14039/Il: Rozwój myśli... Artysta zakończył projekt 7. 07. 1901, co możemy ustalić na podstawie listu z 06. 07. 1901.

${ }^{12}$ Swoje przygotowania do konferencji artysta opisał w liście z 5. 07. 1901: ,...wczoraj cały dzień prawie, zmarnowałem i to na czynnościach dyplomatycznych. Na czwartek naznaczony jest dzień oględzin. Nie chciałem, aby Odrzywolski umyślnie mi potem bruździł, widząc, że jadę dalej ze sklepieniem, chciałem być u biskupa, żeby go odpowiednio przygotować, bo w Odrzywolskim właściwie nic innego, prócz strachu przed biskupem nie siedzi”. - Ossol., rkps nr 14039/II: Rozwój myśli....

${ }^{13}$ W liście z 6. 07. 1901 Mehoffer zamieszcza uwage, że Sokolowskiemu, „żebra się podobały i kolor sklepienia". - Ossol., rkps nr 14039/II: Rozwój myśli...

${ }^{14}$ List z 9. 07. 1901: „Jutro maluje pierwszą grupę, chociaż korona nie wyschła jeszcze”. Ossol., rkps nr 14039/I1: Rozwój myśli.....
} 
wie sierpnia ${ }^{15}$; Mehoffer postanowił jeszcze wprowadzić poprawki we fryzie aniołków, które, wediug niego, Taaiaga wymalował w zbyt ,słodkiej" manierze ${ }^{16}$. Po wykonaniu tej części dekoracji artysta pragnął przystapić do ozdobienia pozostałych partii wnętrza: ,...(kardynała) molestowałam o ściany. Jest ten postęp, że już nie powiada, że samo sklepienie zostanie, tylko, że ściany w przyszłości się namalują że pieniędzy nie ma, etc - że będzie miał dla mnie inną robotę"17.

Na przełomie lat 1902 i 1903 dekoracja malarska skarbca była już prawie doprowadzona do obecnego $\operatorname{stanu}^{18} . \mathrm{Z}$ powyższych uwag wynika, że między końcem sierpnia 1901 (kiedy to ukończono malowidło z fryzem aniołów) i końcem 1902 Mehoffer był zajęty realizacją cyklu geniuszy oraz polichromią w partii ścian, na którą złożyły się kompozycje z archaniołami Michałem i Gabrielem (na ścianie północnej), malowidło $\mathrm{z}$ wizerunkiem Chrystusa na tle krzyża ${ }^{19}$ (na ścianie zachodniej) a także motywy ornamentalne (które stanowią zasadniczą część dekoracji ścian).

Polichromia, którą możemy dziś oglądać w skarbcu, jest tylko jakby ramą wielkich kompozycji figuralnych, które ostatecznie nie zostały wykonane; miały one zdobić cztery wielkie, ostrołukowe pola: trzy na ścianie południowej oraz pole na ścianie wschodniej - ołtarzowej. Zachowała się fotografia ${ }^{20}$ projektu, na którym Mehoffer przedstawił koncepcję dekoracji tychże czterech pól (a także dekoracji ściany północnej, którą zrealizowano, ale w formie zmodyfikowanej). Ten szkicowy projekt (fot.10) jest sygnowany i datowany „1900”, co świadczy o tym, iż artysta pochłonięty był sprawą dekoracji skarbca jeszcze przed podpisaniem kontraktu w marcu roku 1901 i od samego początku nosił się z zamiarem ozdobienia malowidłami całego wnętrza.

Dotychczas, za bezpośrednią przyczynę przerwania prac nad polichromia skarbca uznawano list Karola hr. Lanckorońskiego do kardynała Puzyny a także broszure Lanckorońskiego Nieco o nowych robotach $w$ katedrze na Wawelu ${ }^{21}$, w których autor poddał dzieło Mehoffera ostrej krytyce. Z informacji przedstawionych w Rozwoju myśli twórczej... wynika jednak, że decyzja o zaprzestaniu robót zapadła już wcześniej: "nagle biskup kazał usunąć rusztowanie, mówiąc, że mu się sprzykrzyło tak długo nie móc rozporządzać skarbcem, (...) po liście Lanckorońskiego, kardynał był zadowolony, że kierując się własnym kaprysem,

${ }^{15}$ Co można ustalić na podstawie listu do żony z 14. 08. 1901 - ostatniego z odnalezionych, które dotyczą realizacji polichromii skarbca katedralnego. - Ossol., rkps nr 14039/11: Rozwój myśli....

16 Tamże.

${ }^{17}$ Tamże.

${ }^{18}$ O czym informuje nas Kronika krakowska z roku Pańskiego 1902 [dalej: Kronika 1902], w Kalendarzu Krakowskim Józefa Czecha na rok 1903 [dalej: Kalendarz 1903], s. 99: „Sprawa niemal całkiem ukończoną w roku 1902 jest restauracya wnętrza skarbca katedralnego. Polichromia sklepienia i części ścian tej gotyckiej budowli, przeprowadzona przez prof. Mehoffera będzie chlubą naszego malarstwa dekoracyjnego".

${ }^{19}$ Wg Jadwigi Mehofferowej, na ścianie zachodniej artysta zamierzał pierwotnie umieścić „scenę historyczna, może z czasów Bolesława Chrobrego"; - Ossol., rkps nr 14039/II.: Rozwój myśli....

${ }^{20}$ Fotografia wykonana przez Kriegera po roku 1900. Archiwum Muzeum Historycznego m. Krakowa [dalej: M. Hist. m. Krakowa].

${ }^{21} \mathrm{H}$. L a n c k o r o ń $\mathrm{s} \mathrm{k}$ i, Nieco o nowych robotach w katedrze na Wawelu, Wiedeń 1903. 
kazał usunąć ze skarbca rusztowania"22. W swej broszurze, która ukazała sie w roku 1903, Karol Lanckoroński pisał: ,...wymaga się od kierownika restauracji starego gmachu, przede wszystkim, wielkiego uszanowania przeszłości i wielkiego wyrzeczenia się siebie", opowiadając się tym samym przeciwko jakimkolwiek twórczym działaniom malarskim czy rzeźbiarskim w obrębie zabytkowej budowli. Za uzasadnione uważał przeprowadzenie w katedrze jedynie zachowawczych prac konserwatorskich. Tak więc, kilka ostatnich realizacji we wnętrzu świątyni (czy też ich projekty) oceniał bardzo negatywnie, szczególną dezaprobatę wyrażając wobec mehofferowskiej dekoracji skarbca; warto w zwiazku z tym, zacytować jeden $\mathrm{z}$ charakterystycznych fragmentów jego tekstu: „Sufit skarbca już prawie $w$ całości wypełnił jeden $\mathrm{z}$ najwięcej utalentowanych naszych malarzy postaciami niezliczonych wiejskich chłopaków ze skrzydłami na plecach, przedstawiającemi aniołów, nie-heraldycznymi herbami i najrozmaitszymi ornamentami. Wszystko to namalowane w kolorach nader jaskrawych". Jedyna bezpośrednią repliką na zarzuty zawarte w broszurze Lanckorońskiego był artykuł Józefa Mehoffera Uwagi o sztuce. Odpowiedź na list hr Karola Lanckorońskiego w sprawie restauracji Katedry na Wawelu ${ }^{23}$.

Po zakończeniu prac malarskich $\mathrm{w}$ skarbcu w zasadzie żadne $\mathrm{z}$ czasopism krakowskich nie zdobyło się na poważniejszy artykuł krytyczny ${ }^{24}$. W jednym z numerów Architekta z roku 1902 Władysław Ekielski uznał dekorację skarbca za „dzieło pełne głębokich i głęboko odczutych myśli i pełne koloru” ${ }^{\text {"2s }}$. Na łamach Chimery $^{26}$ w roku 1904 wyrażono zdziwienie, iż polska prasa nie nie zareagowała na artykuł Lanckorońskiego. W 1906 William Ritter w artykule Un peintre polonais Joseph Mehoffer pisał na temat dwóch monumentalnych, nie zrealizowanych projektów malarskich polskiego artysty (tekst Lanckorońskiego przyczynił się bowiem do przerwania prac nie tylko nad polichromią skarbca katedry na Wawelu, ale i w katedrze płockiej): „Jeśli p. hr. Lanckoroński, odbywając jedną ze swych nieustannych podróży, zechce zatrzymać się we Fryburgu, uświadomi sobie, jak celny zadał cios. Pewnym jest, że pozbawił swój kraj równocześnie dwóch arcydzieł podobnej rangi" ${ }^{27}$. Do sprawy nieukończenia polichromii skarbca powrócił w roku 1909 Eligiusz Niewiadomski; wypowiedział się na ten temat, w niezwykle ostrym tonie, w Sfinksie ${ }^{28}$.

${ }^{22}$ Ossol., rkps nr 14039/II: Rozwój myśli....

${ }^{23}$ Kraków 1903 (nakładem autora); rękopis: Biblioteka Narodowa w Warszawie, sygn. BN III 7358. (W wersji niemieckiej artykuł drukowany na łamach „Ver Sacrum”, 1903: z. 14-15, s. 245-261).

${ }^{24}$ Pierwsza próbą oceny dzieła była pochlebna wzmianka w Kalendarzu 1902 (w Kronice 1901), s. 75. Bardzo przychylny, choć krótki komentarz dotyczący polichromii znajdujemy też w Kalendarzu 1903 (w Kronice 1902), s. 99-100.

${ }^{25}$ "Architekt", 3: 1902, nr 5, s. 52.

26" „Chimera", 7: 1904, z. 20-21, s. 446.

${ }^{27}$ W. R i t t e r, Études d'Art étranger, Paryż 1906, s. 167.

${ }^{28} \mathrm{~W}$ artykule, Józef Mehoffer, jako malarz - dekorator, Niewiadomski stwierdzil $\mathrm{m}$. in.: „nawiasem mówiąc, malowania Skarbca nie są właściwie ukończone. To, co M. (Mehoffer) zrobił jest tylko tłem - ornamentowaną rama, dla kompozycji figurowych, które zapewne wykonane nie będa o ile zarząd katedry nie powierzy ich jakiemu śmieciarzowi, jak to niestety bywa udziałem nieszczęsnych katedr polskich”; „Sfinks”, 2: 1909, t. 8, s. 6. 
Karol Lanckoroński, w roku 1912, podjął ponoć próbę pojednania z Mehofferem. Artysta jeđ̉nak nie zareagował na jego propozycję odbycia spotkania $^{29}$.

Przedstawiony poniżej opis ma na celu wykazanie istotnych cech stylistycznych i ikonograficznych dzieła Mehoffera. Składa się on z dwóch części: pierwsza dotyczy zrealizowanej, druga zaś - nie zrealizowanej partii projektu dekoracji malarskiej skarbca.

Skarbiec katedralny to odrębny budynek przyległy do katedry od pólnocnego wschodu. Jest to budowla późnogotycka, z końca wieku XV, trójprzęsłowa, o czteropolowym sklepieniu krzyżowo-żebrowym. Na jej ścianie północnej znajduje się sześć okien, rozmieszczonych w dwóch kondygnacjach. Po stronie zachodniej umieszczony jest barokowy, drewniany chór muzyczny.

$\mathrm{Z}$ r e a I i z o w a n a cześć mehofferowskiego projektu dekoracji malarskiej skarbca obejmuje polichromię sklepienia oraz ścian skarbca, przy czym ściana wschodnia i południowa pokryte są dekoracją malarską do ok. połowy swej wysokości (poniżej nie zamalowanych ostrołukowych płaszczyzn, na które nałożono jedynie warstwę pobiały; fot. 1 a-c). Polichromię wykonano w technice tempery tłustej (fragmenty - w technice olejnej) ${ }^{30}$.

$\mathrm{S} \mathrm{k} l$ e $\mathrm{p}$ i e $\mathrm{n}$ i e jest wymalowane na kolor szafirowy (o odcieniu morskim). Jego dekoracje figuralna (lub raczej figuralno-ornamentalna) stanowi malowidło przedstawiające „chór” aniołków (fot. 2). Anioły, wyobrażone w parach, po dwóch stronach osi sklepienia grupują się w dwa równoległe szeregi. Są to postacie dzieci, przeważnie dziewcząt, o słowiańskich rysach, wyraźnie zindywidualizowane (twarze ich malowane są w technice olejnej) ${ }^{31}$. Wiele elementów tej kompozycji (aureole, układ rąk i skrzydełek aniołów a także trzymanych przez nie złotych gwiazd) przesądza o jej rytmiczności, z większej zaś odległości daje odczucie symetrii. Pary aniołów najbliżej zworników ujęte są w kwiatowy, stylizowany ornament, okalający zworniki z czterech stron. Profilowane żebra zdobi stylizowany ornament roślinny, który przypomina liście rozwijające się z pąków.

Polichromia w dolnych partiach sklepienia ponad wspornikami, na płaszczyznach pomiędzy żebrami spływającymi na ściany, obejmuje dwie grupy przedstawień figuralnych (przy ścianie zachodniej zastapiono je motywem stylizowanych słońc): a - geniuszy młodzieńczych, w polach frontalnych ${ }^{32}$ oraz $\mathrm{b}$ - geniuszy w kompozycjach trójpostaciowych, w bocznych polach

${ }^{29}$ Ossol.: rkps nr 14039/II: Rozwój myśli...

${ }^{30}$ Informacja wg: Dokumentacja Konserwatorska Polichromii Ścian i Sklepienia Skarbca Katedry na Wawelu, Kraków 1998 (mps w posiadaniu autorów). Opr.: Ewa C z u b a - P a w e le c, Adam R a c h t a n.

${ }^{31}$ Zachował się projekt fragmentu polichromii sklepienia, przedstawiający pięć par aniołów; odpowiada on dekoracji malarskiej każdego z półprzęseł. Muzeum Narodowe w Krakowie [dalej: MNKr], nr inw. III-r.a. 152259; Akwarela [dalej: akw.], papier [dalej: pap.] naklejony na płótno [dalej:pł.]; 203 x 119 cm; sygn.: „Józef Mehoffer/1901".

${ }^{32} \mathrm{~W}$ sumie, w dekoracji skarbca występuje dziesięc przedstawień geniuszy „a”: osiem w grupach dwupostaciowych (każdy z geniuszy w polu między dwoma żebrami) oraz dwa przedstawienia pojedynczych geniuszy w polach przylegających do ściany wschodniej. Przy ścianie zachodniej malowidła z młodzieńczymi geniuszami zastapiono motywem stylizowanych słońc (widocznych na fot. 4). 
między żebrami i ścianą ${ }^{33}$ (fot. 3). Dolną ramę ornamentalną każdej z tych kompozycji stanowi stiukowa, stylizowana „,korona”, pokryta pozłotą i zdobiona symetrycznie rozmieszczonymi kaboszonami, wzorowana zapewne na koronie króla Kazimierza Wielkiego. Geniusze (i słońca) przedstawiono na tle stylizowanych, złocisto-czarno-białych płomieni, tworzących nad poszczególnymi postaciami jakby ozdobne „nimby".

Geniusze ,a" to kilkunastoletni, uskrzydleni chłopcy, znaczeni na piersiach złocistymi językami ognia. Dominującą cechą tej grupy figuralnej jest spokój, statyka.

Druga grupa przedstawień geniuszy $-\left(, \mathrm{b}^{\prime \prime}\right)^{34}-$ jest tematycznie i formalnie bardzo różnorodna. Są to postacie również uskrzydlone. Języki ognia znaczą ich czoła. Geniusze każdej trójpostaciowej kompozycji są w zbliżonym wieku; gdy przesuwamy się od ściany ołtarzowej w kierunku zachodnim, ich wiek, w kolejnych kompozycjach, stopniowo wzrasta. W odróżnieniu od geniuszy „a", sa one pełne dramatyzmu, ekspresji (zob. fot. 3). Prezentują szeroką gamę uczuć, uwydatnioną przez sugestywną mimikę i gestykulację (por. fot. $3 \mathrm{~b}$ i 3f). Wiele z nich wzrok i wymowne, żywe gesty kieruje ku ścianie ołtarzowej.

Ś c i a e e $\mathrm{zach}$ odn i a w ostrołuku ponad chórem zdobi kompozycja o charakterze eklektycznym, wyglądająca jak powiększona średniowieczna miniatura (fot.4). Jej centralnym motywem jest przedstawienie twarzy Chrystusa, które przypomina wizerunki z bizantyńskich mandylionów, umieszczone na tle czteroramiennego krzyża (tzw. „lotaryńskiego") ponad symbolami eucharystycznymi oraz literami alfa i omega. Przedłużenie ramion krzyża stanowi ornament w postaci dwupasmowej plecionki o genezie roślinnej (podobny motyw pojawia się też ponad wspornikami, w sąsiedztwie ściany ołtarzowej; fot. 1a, b, c), nawiązujący do ornamentyki przedromańskiej, szczególnie zaś zbliżony do północnogermańskiej plecionki wstęgowej. Malowidło na ścianie zachodniej charakteryzuje się wysokim stopniem stylizacji, jego kompozycja oparta jest na symetrii.

Dekorację figuralną ściany północnej stanowią dwa malowidła, które przedstawiają Archaniołów Michała i Gabriela ${ }^{35}$ (fot. 1c, 5a-c).

${ }^{33}$ Przy ścianie zachodniej, na każdym z dwóch szerokich pól między żebrem i ściana, zamiast trójpostaciowych kompozycji z geniuszami wyobrażono ornamentalne motywy słońc (j.w.); podobnie - w dwóch sąsiednich grupach przedstawień, w analogicznych polach od strony zachodniej. W polichromii występuje osiem trójpostaciowych kompozycji z geniuszami.

${ }^{34}$ Sześć projektów geniuszy „b” znajduje się w Muz. Maz., fot. 3a-3f [pięć z nich to depozyty (ND 499-503) - rysunki węglem, pap.; jeden projekt stanowi wł. Muz. Maz. (S/4417) - wykonany w technice mieszanej na pap., naklejonym na pł., sygn.: „Jozef Mehoffer"], dwa zaś - w MNP [wł. MNP (Gr 846 i Gr 915), akw., pap. naklejony na pł.] Pomiędzy projektami, a ich realizacją występują pewne różnice.

${ }^{35}$ Projekty kompozycji z archaniołami stanowią własność MNP. Akw., pap. naklejony na pł. Obydwu sygn.: „Józef Mehoffer”; „Archanioł Michał” - nr inw. Gr 594, 415 x 143 cm; „Archaniol Gabriel" - nr inw. Gr 595, 406 x $143 \mathrm{~cm}$. - Zachowały się również dwa szkice rysunkowe - studia do postaci Archanioła Michała (wł. pryw., rys. ołówkiem, pap.): a) szkic ręki dzierżacej miecz (z adnotacją o dołu: „Anioł Wojny/ Ręka Wandy Janakowskiej, Skarbiec Wawel”.), b) szkic dolnej partii postaci Archanioła, proponujący inne, niż zrealizowane rozwiazanie stroju: szarfę, a nie skórzany pas (na dole adnotacja: „Skarbiec, Anioł Wojny.”). 
Usytuowane sq̨ w pierwszym i drugim przęśle od wschodu, na płaszczyznach po lowej stroñie okien drugiej kondygnacji, na wysokości dolnej granicy glifów okiennych. Archanioły „stapaja” po pasie ornamentów roślinnych, zdobiących dolną partię ścian. Ich postacie tworzą kompozycyjną całość z dekoracją ornamentalną płaszczyzn przyokiennych po lewej i prawej stronie każdego okna: stylizowanymi, wielobarwnymi kwiatami na łukowato wygiętych łodyżkach.

Archanioł Wojny - Michał (fot. 1c, 5a) wyobrażony został w dynamicznej, marszowej pozycji. W prawej ręce dzierży ognisty miecz, dłonią zaś lewej, w geście rozpaczy, dotyka czoła; na jego twarzy maluje się wyraz głębokiego smutku, zwątpienia. Krój tuniki, jak również sznurowane sandały upodobniają strój Archanioła Michała do stroju rzymskiego legionisty. Na biodrach jest on przepasany szerokim, skórzanym pasem, przypominającym pasy góralskie, a przez ramię przewiesił kościany róg. Archanioł Pokoju - Gabriel (fot. 5b, 5c) kroczy powoli, spokojnie. Zdaje się przyglądać gałąze oliwnej (czy może wierzby), którą trzyma w prawej dłoni. Jego twarz o delikatnych, dziewczęcych rysach wyraża pogodne zamyślenie. Ubrany jest w błękitną koszulę, długą do kolan, przewiązaną w pasie szeroka, wzorzystą szarfą która przypomina pas kontuszowy. Nosi buty o wysokich, marszczonych cholewach, w kolorze czerwonym. Niezwykle ozdobnym elementem obydwu przedstawień archaniołów są ich okazałe, wielobarwne skrzydła.

Wszystkie śc i a n y $\mathrm{s} \mathrm{k} \mathrm{a} \mathrm{b} \mathrm{c} \mathrm{a} \mathrm{poniżej:} \mathrm{przedstawień} \mathrm{figuralnych} \mathrm{ścia-}$ ny północnej, nie zamalowanych ostrołukowych płaszczyzn ściany wschodniej i ściany południowej (fot. 1a-c), a także ścianę zachodnią poniżej chóru wypełnia dekoracja ornamentalna, w której dominuja motywy o genezie roślinnej. W jej obrębie można wyróżnić kilka poziomych stref ornamentów (zob. fot. 6). Szczególnie interesująco została rozwiązana górna strefa ornamentyki na ścianie północnej: tworzy ją motyw nakładających się na siebie, trójkątnie zakończonych zielonych pączków kwiatowych (fot. 1c, 5a, 5c); pączki najniższego rzędu zostały przedstawione $\mathrm{w}$ przekroju podłużnym, $\mathrm{z}$ uwidocznionymi słupkami i pręcikami; przypominaja rozrysy koron kwiatowych ze wzorników botanicznych. Dominującą barwą tej partii malowideł jest zieleń. Występuje również czerwień i róż, $\mathrm{z}$ akcentami koloru żółtego i złoceń.

Kończąc opis zrealizowanej partii projektu polichromii skarbca, należy wspomnieć o d e k or a c j i g l i fó w ok i e n n y c h. Najciekawszy ornament tej części polichromii oparty jest na motywie węży wijących się wśród róż ${ }^{36}$ (fot. 7); zdobi on wąskie, wewnętrzne glify podwójnie rozglifionych okien (fot. $8 \mathrm{a}, 8 \mathrm{~b})$. Ornament ten jest silnie przestylizowany, jak zauważa Helena Blum ${ }^{37}$, jest niemal abstrakcyjny.

Ponadto, w zewnętrznych, szerszych glifach, po dwóch stronach każdego $\mathrm{z}$ okien wprowadzono motywy heraldyczne: - litewskiego herbu-Pogoni (w oknach dolnej kondygnacji; fot. 1c, 8a) i - Orła jagiellońskiego (w oknach kondygnacji górnej; fot. 1c, 8b). Te stylizowane przedstawienia mają duże wa-

${ }^{36}$ Projekt „Węże wśród róż" - dep. w MNKr, ND 8572. Akw., pap., naklejiony na pł. $46 \times 100 \mathrm{~cm}$. Sygn. ,JM".

${ }^{37}$ H. B I u m, Wstęp do Katalogu Wystawy Zbiorowej Józefa Mehoffera, Kraków, 1964, s. 45. 
lory dekoracyjne. Malowidła każdej z dwóch wymienionych grup różnią się między sobą opracowaniem detali.

Jednym z n i e z r e a li z o w a n y c h projektów polichromii skarbca jest k o m p o z y c j a ,Z a c hw y c o n e A n i o ł y"38 (fot. 9), która przedstawia dwie postacie dziewczęcych aniołów, ,zapatrzonych" w jedną stronę, o mimice i gestykulacji wyrażającej zdumienie, zachwyt. Projekt ten to pierwotna wersja dekoracji figuralnej d ol n y c h p a r t i i $\mathrm{skl}$ e p i e n i a; fakt ten potwierdzają pisemne wypowiedzi artysty (przytoczone poniżej); ponadto, w malowidle pojawiają się motywy ornamentalne, które w nieco tylko zmodyfikowanej formie zostały powtórzone w zrealizowanych przedstawieniach geniuszy.

O tym, jak miały wyglądać cztery wielkie k om p ozycje figuralne w ostrołukowych polach ściany wschodniej i ściany $\mathrm{p}$ o ł $\mathrm{u} \mathrm{d} \mathbf{n} \mathrm{i}$ o w e $\mathrm{j}$ informuje nas projekt polichromii skarbca znany $\mathrm{z}$ fotografii Kriegera $^{39}$ (fot. 10). Składa się on z trzech prostokątnych kompozycji - malarskich szkiców dekoracji ścian: północnej, wschodniej i południowej (skoncentrujemy się na omówieniu kompozycji narracyjnych, które miały zdobić ścianę wschodnią i południowa). Szkicowość projektu, jak również konieczność posłużenia się fotografią jako jedynym materiałem źródłowym, utrudniają jednoznaczne rozpoznanie tematyczne, a przede wszystkim analizę stylistyczną dzieła.

Kompozycja środkowa to studium polichromii ściany wschodniej. Wyobrażono na niej Matkę Bożą z Dzieciątkiem ukazującą się na tle nieba, w otoczeniu aniołów (zdają się tu również występować inne przedstawienia figuralne). Marię adoruje skupiona u jej stóp grupa świętych, w której wyróżniają się, widoczne po prawej i lewej stronie, dwie postacie klęczących biskupów. Boczne partie kompozycji wypełniają przedstawienia stojących szeregiem pieszych i konnych rycerzy. Na całej długości podstawy ostrołukowego pola widnieje napis: „Boga Rodzico Dziewico Bogiem Sławiona Maryo". Temat tego malowidła jest nieco problematyczny. Władysław Kozicki ${ }^{40}$, w oparciu o cytowany wyżej napis, tytułuje go: „Rycerstwo polskie śpiewające przed bitwą pieśn 'Bogarodzica" ". Mehoffer w jednym $\mathrm{z}$ wywiadów ${ }^{41}$ wspominał wielką kompozycję, „dającą tło ołtarzowi”, na którą zostawił puste miejsce, „równe wielkością Grunwaldowi”. Opinia Kozickiego i wypowiedź Mehoffera sugerowałyby więc, iż projektowane malowidło miało przedstawiać bitwę pod Grunwaldem. Z drugiej strony jednak, jego układ $\mathrm{i}$ treść (np. niezgodność $\mathrm{z}$ relacją Długosza) stawia tę tezę pod znakiem zapytania. Wydaje się, że scena niniejsza nie dotyczy konkretnego faktu historycznego; jest to raczej wyobrażenie zbiorowej modlitwy, którą do Matki Bożej kierują postacie z polskich dziejów, przede wszystkim zaś polscy święci.

${ }^{38}$ Dep. w MNKr, ND 7783. Tempera, tynk; 95 x 82 cm; sygn.: „Mehoffer”.

${ }^{39}$ Projekt wykonano w technice mieszanej (olówek, tusz, akw., pap.). Wymiary nie znane. Sygn.: „Józef Mehoffer / 1900”. Oprawny w prostokątną ramę. (Zob. też przypis 20). Zachowały się również szkice do wspomnianego projektu, które prezentują koncepcję dekoracji ścian północnej i południowej; rysunki ołówkiem, pap. Wł. pryw.

${ }^{40}$ W. K o z i c k i, Józef Mehoffer "Sztuki Piękne", 3: 1927, nr 9, s. 398.

${ }^{41}$ Zob. artykuł Twórca tęczy - rozmowa z prof. J. Mehofferem „A,B,C-Nowiny Codzienne", 1935 , nr 45. 
Prostokątna kompozycja po prawej stronie omawianego projektu to szkic dekoracji trzech ustrołukowych płaszczyzn ściany południowej. Jest on bardzo słabo czytelny. Tematem sceny figuralnej, która miała być umieszczona w polu najbliższym ścianie wschodniej jest wjazd Chrobrego do Kijowa. W środkowej kompozycji wyobrażono Kazimierza Wielkiego (jako władcę, który przyczynił się do spisania i ujednolicenia praw), bądź też fakt nadania przywilejów Akademii Krakowskiej przez Władysława Jagiełłę. Możemy przyjąc hipotezę, że w ostrołukowym polu w prześle chóru Mehoffer zamierzał przedstawić królową Jadwigę modlącą się przed krucyfiksem wawelskim ${ }^{42}$.

Zachował się drobny rysunek: szkic postaci króla w reprezentacyjnym stroju (fot. 11). Po prawej stronie kompozycji zamieszczono informację: „Do skarbca na Wawelu 1900 r.”, w jej zaś górnej partii dłuższą notatkę ${ }^{43}$ i napis "Piast" - zapewne tytuł rysunku. Do kwestii znaczenia tego niepozornego szkicu wrócimy poniżej.

Polichromia skarbca katedralnego składa się z partii figuralnej i ornamentalnej, ściśle ze sobą zespolonych.

Pewne cechy stylistyczne figuralnej partii polichromii (zrealizowanej części projektu) należą do zestawu środków formalnych malarstwa realistycznego; malując wizerunki aniołów i geniuszy artysta opierał się na studium z natury; dążył do wiernego przedstawienia fizjonomii, usiłował unikać idealizacji; akcesoria kostiumologiczne odtworzył drobiazgowo, opracował precyzyjnie detale (co widoczne jest przede wszystkim w przedstawieniach archaniołów i geniuszy „a"); zastosował światłocieniowy - aczkolwiek dość umiarkowany - modelunek postaci. Z drugiej strony, dzieło Mehoffera odznacza się wieloma cechami nowatorskimi i wykracza poza reguły malarstwa realistycznego; kompozycje figuralne polichromii zostały umieszczone na płaskim tle; charakterystyczną ich cechą jest linearyzm, zaznaczający się szczególnie w partii strojów kształtowanych wyraźnym, czasem ostro łamiącym się konturem; pewne grupy postaci (anioły na sklepieniu) tworzą układy zbliżone do ornamentalnych; stroje, skrzydła oraz inne akcesoria aniołów, archaniołów i geniuszy są bardzo ozdobne (zob. np.: tunika Archanioła Michała, czy szarfa, którą przepasany jest Archanioł Gabriel, dekorowane bogatym zestawem ornamentów roślinnych); przedstawienia figuralne wkomponowano w ozdobne ornamentalne ramy (zob. stylizowane, złote płomienie w malowidłach $\mathrm{z}$ geniuszami), niekiedy przenikają się one z partią ornamentalną (archanioły, które „wkraczaja”" w strefę ornamentu roślinnego). Tak więc, część figuralna polichromii posiada wybitne walory dekoracyjne, nadrzędne względem jej funkcji treściowych. Zespół środków wyrazowych dzieła został wzbogacony o cechy silnej ekspresji, dramatyzmu, którymi charakteryzują się trójpostaciowe kompozycje z geniuszami i malowidło z Archaniołem Michałem.

\footnotetext{
42 Tytuły kompozycji historycznych przeznaczonych na ścianę pohudniową podano w oparciu o katalog M. Hist. m Krakowa (środkową kompozycję tytułuje się tam: „Kazimierz Wielki”).

${ }^{43}$ Wl. pryw. Rys. ołówkiem, pap. W górnej parti szkicu, pod napisem „Piast”, notatka: „Św Cyryl Metody./ Św. Wojciech, ciało jego kupiono na wage złota. $/ \uparrow 997 /$ Św. Stanisław $\uparrow 1079 /$ Otto biskup bamberski. 1124 (Gallus) / powstanie choragwi narodowej".
} 
Ich przeciwwagę stanowią bardziej spokojne, statyczne wyobrażenia geniuszy młodzieńczych „a" oraz - Archanioła Gabriela. Cztery wielkie, jedynie zaprojektowane kompozycje historyczne miały być zapewne oparte na bardziej tradycyjnych środkach wyrazu; choć nie sa pozbawione znamion dekoratywności, to jednak współczynnik stylizacji jest w nich znacznie mniejszy niż w przedstawieniach figuralnych zrealizowanego fragmentu koncepcji Mehoffera.

Wśród ornamentów ilościowo dominują motywy o pochodzeniu organicznym, głównie roślinnym, które odznaczają się daleko posuniętą stylizacją, czasem wydają się wręcz abstrakcyjne (zob. ornament „Węże wśród róż”, fot. 7); przeważa roślinna ornamentyka wypełniająca, o charakterze ciaggłym. Kompozycja partii ornamentalnej jest w znacznej mierze oparta na symetrii; większość ornamentów polichromii ma strukturę wieloosiowa (np. ornamenty na ścianach, fot. 6, czy malowidła z kwiatami opasujące zworniki, fot. 2). Charakter niemalże ornamentalny posiadają motywy heraldyczne: Orły jagiellońskie, przedstawienia Pogoni, stiukowe „korony” na koszach. Za kompozycję ornamentalną można też uznać malowidło na ścianie zachodniej, w którym motywy tematyczne o różnorodnym pochodzeniu tworzą niezwykle dekoracyjną całość.

Już na wiele lat przed przystapieniem do polichromii skarbca, Mehoffer snuł projekty ozdobienia monumentalnymi malowidłami wnętrza katedry wawelskiej; jeden ze swoich młodzieńczych zamysłów opisał w roku $1895^{44}$. Jest to wielka, ekstatyczna wizja, w której wszystko „łączy się w jeden wielki krzyk - Gloria!, Gloria!, biegnie od jednego końca kościoła, w drugi i potężnieje gdzieś na górze”. W kompozycjach na ścianach światyni artysta zamierzał przedstawić to, „,co myśl zwodzić może, pobudzona jednym słowem 'ojczyzna' „. Pragnął więc wyobrazić „zmartwychwstałe hufce”, sztandary, „konnych i pieszych w żelazo zakutych”, wśród których „kwiatów i palm pełno”. Przytoczmy ponownie słowa Mehoffera: „grupy się zmieniaja, a każda jest jednym wielkim kwiatem kolorów, rzuconym na białe ściany. Niżej, ku dołowi, rozpacz miniona i dzisiejsza i ostatnie wypadki wyraz swój znajdą. Krew z Krożów, boleść w Warszawie. Gdzieś indziej znów, sztandary nieprzyjaciół pobrane, ojczyzna smutna i radosna (...). Wreszcie pieśni polskie, to co wyrażają Boże coś Polskę, $Z$ dymem pożarów i reszta. I powinno wszystko, co namalowane wołać: 'Jeszcze nie zginęła' ". Opis ten może być punktem wyjścia do rozważań nad tematem polichromii skarbca. Mehofferowskie idee wielkiej dekoracji malarskiej we wnętrzu katedry stoją bowiem u podłoża idei polichromii skarbca.

W jej koncepcji treściowej zasadniczą rolę miały odegrać cztery monumentalne kompozycje historyczne, które ostatecznie nie zostały zrealizowane. Ideowym ośrodkiem dekoracji malarskiej skarbca, jej ,,punktem najświetniejszym"45 byłaby - zgodnie z zamierzeniem Mehoffera - kompozycja na ścianie wschodniej. Przedstawienie ważnych wydarzeń z polskiej historii miało więc stanowić bazę treściową dzieła. Ideę zaś nadrzędną - szczególnego znaczenia w dziejach Polski zwierzchnictwa Matki Bożej - wyrażałaby kompozycja centralna. Me-

${ }^{44}$ Ossol.: rkps nr 14039/II: Rozwój myśli ....

${ }^{45}$ Tamże. 
hoffer zamierzał ją uczynić niejako ilustracja wezwania z najstarszej polskiej pieśni; zauważmy iż wcześniej, w maiowidłach na ścianach katedry, pragnął przedstawić to, „,o wyrażają pieśni polskie”.

Mniej jednoznaczna i trudniejsza do odczytania jest idea wykonanej części polichromii, która miała być „oprawa”. dla zaprojektowanych przez artystę malowideł historycznych.

W jednym ze swych listów Mehoffer wypowiedział się - aczkolwiek dość fragmentarycznie - na temat genezy i znaczenia kompozycji z geniuszami; wyjaśnił, dlaczego zrezygnował z wykonania projektu „Zachwycone Anioły” (fot. 9): „odstapiłem od Aniołów, zamiast nich robią się 'geniusze narodowe', uskrzydlone, z płomieniami nad czołami (...). Anioły nie maja sensu, bo one, jako duchy wyższe, nie moga przebywać tych uczuć, jakie w ludziach się budza, po ciężkich doświadczeniach, a tam właśnie uczucia miały być główną rzeczą"*46. Malowidła w dolnych partiach sklepienia przedstawiają zatem, zgodnie z zamysłem artysty, „geniusze narodowe". „Geniusz", w najbardziej podstawowym znaczeniu tego słowa, to duch, natomiast geniusze z polichromii skarbca to istoty duchowe, ale zarazem ludzkie, gdyż to właśnie ludzie obdarzeni są zdolnością odczuwania cierpienia. Zauważmy, że przedstawienia geniuszy „b” mają charakter portretowy. Niezwykle istotny jest fakt, że niektóre $z$ nich $^{47}$ to wizerunki wybitnych twórców polskiej kultury. I tak, obok portretu Mickiewicza, (w kompozycji wg projektu „Geniusze III”, zob.: przypisy, p. 7, fot. 3d), namalowanego na podstawie jego maski pośmiertnej z Montmorency, zauważamy wizerunek Słowackiego (fot. j.w.). Wiadomo, iż $\mathrm{w}$ fizjonomiach geniuszy Mehoffer utrwalił też rysy wielu postaci współczesnych ${ }^{48}$; wśród malowideł tych dostrzegamy istotnie podobiznę Stanisława Wyspiańskiego, Włodzimierza Tetmajera, Lucjana Rydla (fot. 3e, 3f).

Tak więc, mehofferowskie „geniusze narodowe” to jednostki o charakterze na poły duchowym, współuczestniczące w dramatycznych, narodowych doświadczeniach. Określenie to można interpretować w oparciu o potoczny sens słowa „geniusz", które oznacza osobę o wybitnych walorach intelektualnych; taka interpretacja znajduje swe uzasadnienie w dokonanym powyżej rozpoznaniu ikonograficznym.

Idea kompozycji figuralnych w dolnych partiach sklepienia wiąże się ściśle z problematyką patriotyczno-niepodległościową. Jest zasadniczym elementem programu, który Mehoffer sformułował już wówczas, gdy rozmyślał o stworzeniu we wnętrzu katedry monumentalnych malowideł, wyobrażających to, „co myśl zwodzić może, pobudzona jednym słowem 'ojczyzna'": pomysł kompozycji $\mathrm{z}$,geniuszami narodowymi" wyrasta z tych właśnie młodzieńczych wizji artysty. Program ikonograficzny polichromii skarbca czerpie z polskiego romantyzmu ze spirytualistycznej koncepcji narodu i historii, z literatury, która podejmowała problem „wybawienia” narodu (jednym ze źródeł inspiracji mógł być dla Me-

\footnotetext{
${ }^{46}$ List do żony z 26. 06. 1901. Ossol.: rkps nr 14039/II. - Rozwój myśli...

${ }^{47}$ Czyli co najmniej tych kilka przedstawień geniuszy, które udało się zidentyfikować.

${ }^{48}$ Informację tę podaje R i t t e r, Études..., s. 165.
} 
hoffera poemat Juliusza Słowackiego Genezis z ducha); owo wybawienie, zgodnie z poglądami mesjanistycznymi, miało dokonać się poprzez przebycie licznych doświadczeń, cierpień, a one właśnie są tematem wyobrażeń geniuszy. Podjęcie tego wątku przez Mehoffera można uznać za przejaw neoromantyzmu; jednym z czynników tej ważnej tendencji kulturowej przełomu wieków była działalność Wincentego Lutosławskiego, propagatora idei polskiego mesjanizmu ${ }^{49}$.

Kompozycja w górnej strefie polichromii skarbca nasunęła Williamowi Ritterowi skojarzenie ze sceną Zesłania Ducha Świętego ${ }^{50}$. Za taką interpretacją przemawia fakt ,naznaczenia" geniuszy, na czołach lub na piersiach, płomieniami („płomień naznacza ich czoła, w miejscu rany na czaszce św. Piotra męczennika..."). Układ zaś trójpostaciowych malowideł - na których geniusze zostały przedstawione jakby w ,grupach wiekowych" (zob. opis) - pozwala domniewywać, iż Mehoffer odwołał się tu również do tekstu proroctwa Joela ze Starego Testamentu $(3,1)$ : „Wyleję Ducha mego na wszelakie ciało, a wasi synowie jak i córy wasze - będa prorokowali; wasi młodzieńcy widzenia mieć będą, a wasi starcy będą śnili we śnie".

By prawidłowo zinterpretować treść niniejszych wyobrażeń należy zwrócić uwagę na niektóre ich cechy formalne. Tak więc, postacie geniuszy swe zainteresowanie zdają się kierować w jedną stronę. Znajdują się w stanie ekstazy; domyślamy się, że są świadkami jakiegoś niezwykłego, czy wręcz metafizycznego wydarzenia, uczestniczą we wspólnej wizji (co szczególnie wymownie wyrażają gesty geniuszy z pełnych dynamizmu kompozycji trójpostaciowych; zob. np. „Geniusze IV", fot. 3e). Sa aktorami rozgrywającego się właśnie dramatu. W malowidłach zdobiących dolne partie sklepienia Mehoffer nawiązał do pewnych barokowych założeń dekoracyjnych - tych, w których na wielką skalę stosowano efekty teatralne (wspomnijmy np. zespoły rzeźbiarskie Berniniego, szczególnie wystrój kaplicy Cornaro - żeby wymienić najbardziej charakterystyczne i powszechnie znane przykłady).

Tematyka kompozycji z geniuszami koncentruje się wokół wyzwolenia, czy raczej „wybawienia” narodu; zespół tych przedstawień kojarzy się z teatralną inscenizacja; trudno nie dostrzec związku pomiędzy sceną zbiorowej wizji w górnej partii polichromii skarbca i ostatnim aktem Wesela Stanisława Wyspiańskiego (prapremiera dramatu odbyła się w marcu $1901 \mathrm{w}$ Teatrze Słowackiego). Zwróćmy uwagę, że uczestnikami sceny wyobrażonej w górnej partii polichromii Mehoffer uczynił osoby współczesne, z bliskiego sobie kręgu (jak wspomniano wyżej, ich podobizny zostały umieszczone obok wizerunków postaci historycznych, np. wieszczów) - jest to zabieg identyczny z tym, do którego odwołał się autor Wesela (nie ma tu oczywiście mowy o bezpośrednich, świadomych inspiracjach).

Wydaje się ponadto, iż wykorzystując w polichromii motywy o genezie biblijnej (nawiązanie w kompozycji z geniuszami do sceny Zesłania Ducha Świę-

${ }^{49}$ Szereg swoich poglądów zawarł Lutosławski w Wyktadach Jagiellońskich, Kraków 1902 (t. 1: Wykłady wstęne, Kraków 1901).

${ }^{50}$ R itt e r, Etudes..., s. 164-165. 
tego), Mehoffer podjął próbę sakralizacji zawartych w dziele treści narodowych; i ta postawa ma źródło w literaturze i filozofii polskiego romantyzmu.

Postacie archaniołów Michała i Gabriela rozszerzają tę koncepcję ideową o nowe znaczenia. W ich wyobrażeniach Mehoffer w bardzo ograniczonym stopniu nawiazzał do tradycji ikonograficznej, temat ten ujął w sposób nowy, w pełni indywidualny. Archanioł Michał z polichromii skarbca nie jest ani zbrojnym rycerzem ważącym dusze na Sądzie Ostatecznym, ani jeźdźcem, który walczy $\mathrm{z}$ demonami. Jedynym tradycyjnym motywem jest tu jego ognisty miecz. Zupełnie nietypowy jest również strój tego archanioła, łączący elementy ubioru rzymskiego legionisty z elementami stroju ludowego, góralskiego, przy czym te ostatnie zdecydowanie w nim dominują. Archanioł Gabriel natomiast, którego najczęściej wyobrażano w scenie Zwiastowania, w polichromii Mehoffera zyskuje rangę samodzielnego tematu. Gałąza oliwna, którą trzyma w dłoni (choć i tak zbliżona wyglądem do gałąki wierzby) to w zasadzie jedyny detal z jego wcześniejszych przedstawień. W ubiorze Gabriela odnajdujemy przede wszystkim reminiscencje polskiego stroju szlacheckiego oraz ludowego - krakowskiego (szarfa przypominająca pas kontuszowy, buty o wysokich, przymarszczonych cholewach w kolorze czerwonym). W malowidłach $\mathrm{z}$ archaniołami Gabrielem i Michałem Mehoffer wyeksponował ich rolę posłańców - zwiastunów pokoju i wojny. Są tu oni symbolami tych głównych czynników filozofii dziejów.

Archanioły zostały więc obdarzone cechami tradycyjnie polskimi, ludowymi, co ma swój szerszy kontekst. Do wyobrażenia tych dwóch anielskich postaci a także słowiańskich, dziecięcych aniołów na sklepieniu Mehoffera mogły zainspirować ludowe obrzędy: widowiska kolędnicze, jasełka, szopki; na przestrzeni wieków motywy religijne były w nich bowiem wzbogacane, a stopniowo nawet zostały zdominowane przez elementy rodzimego folkloru. $\mathrm{O}$ takich wpływach świadczy szczególnie kompozycja malowidła na sklepieniu: układ grup anielskich nasuwa skojarzenie z szopka, w której anioły umieszczone sq̨ u góry, symetrycznie po dwóch stronach (pisał o tym Jędrzej Kitowicz: „W górze szopki, pod dachem, i nad dachem, aniołkowie, unoszący się na skrzydłach, jakoby śpiewający Gloria in excelsis Deo"51).

Tak więc, wszystkie przedstawienia figuralne polichromii skarbca tworzą ideową całość o cechach rozgrywającego się dramatu, inscenizacji teatralnej, której pewne elementy zostały przejęte $\mathrm{z}$ ludowego widowiska.

Program ideowy dzieła dopełnia symbolika ornamentów roślinnych: jest to symbolika rozrostu, bujności, sił rozrodczych przyrody, a więc akcentująca pierwiastki witalne.

W polichromii skarbca katedralnego ujawnił się całkowicie już skrystalizowany styl Mehoffera. Po raz pierwszy w pełni zostały tu wykorzystane środki wyrazu znamienne dla mehofferowskiego stylu dekoracji malarskiej wnętrza, takie jak: „logiczna" kompozycja całości, dostosowana do artykulacji ścian, strefowy układ ornamentów (najczęściej zgrupowanych w poziomych pasach), sy-

51 J. K i tow i c z, Opis obyczajów $i$ zwyczajów za panowania Augusta III, Wrocław 1951, s. 60 (pierwsze wydanie - Poznań 1840-1841). 
metria i „rytmiczny" układ motywów, daleko posunięta stylizacja, syntetyzm, a nawet geometryzacja formy (szczególnie w partii ornamentalnej; stylizacji podlegają jednak również kompozycje figuralne), stosowanie w dużym natężeniu ozdobnych akcesoriów i elementów zdobniczych: złoceń, stiuków, imitacji kaboszonów (Tadeusz Dobrowolski ${ }^{52}$, w związku z tą ostatnią cechą zwrócił uwagę na efekt „,bizantynizmu” polichromii mehofferowskich), czerpanie z różnych źródeł inspiracji i łączenie rozmaitych motywów ikonograficznych w nowe schematy o dużej wymowie dekoracyjnej.

Dekoracja malarska skarbca jest pierwszym dziełem, w którym Mehoffer na szeroką skalę wprowadził ornamentykę typową dla swego dojrzałego stylu. Ma ona odrębna, tylko sobie właściwą formę. Jest zupełnie odmienna od ornamentyki roślinnej Wyspiańskiego, która opiera się na motywach traktowanych niemal realistycznie (zob. polichromia kościoła Franciszkanów) i o której wyrazie rozstrzyga kaligraficzna, ekspresyjna linia; w ornamentyce polichromii skarbca współczynnik linearyzmu jest stosunkowo mały, nie należy jej więc definitywnie kwalifikować jako „secesyjnej". Trudno stwierdzić, czy i w jakim stopniu oddziałały na nią dzieła współczesnego malarstwa dekoracyjnego lub sztuki zdobniczej. Pewnych do niej analogii, ze względu na jej ciagła strukturę, charakter wypełniający, czy zrytmizowanie kompozycji możemy dopatrzeć się w deseniach ozdobnych tkanin projektu Voyseya. Występujący w polichromii skarbca ornament plecionkowo-wstęgowy (fot. 4) był jednym z ważnych elementów ornamentyki szkockich twórców Art Nouveau (szkoła z Glasgow). Pąki przedstawione $\mathrm{z}$ dużą dokładnością $\mathrm{w}$ pionowym przekroju (w górnej części pasa ornamentacji roślinnej, fot. 5a, 5c) przypominaja z kolei anatomiczne rozrysy koron kwiatowych z bardzo wówczas popularnych „wzorników roślinnych"53.

Na kształt partii ornamentalnej polichromii skarbca w sposób decydujący wpłynęła sztuka ludowa. Mehoffer wprowadził charakterystyczne dla tejże sztuki motywy (np. stylizowanych, wielobarwnych kwiatów, fot. 1c, 5b, czy kwiatów polnych, fot. 6), co zaś istotniejsze, odwołał się do jej zasad kompozycyjnych. Najważniejszą $\mathrm{z}$ nich jest symetria, przejawiająca się $\mathrm{w}$ wieloosiowej strukturze ornamentów (dotyczy to szczególnie ornamentów wokół zworników, zob. fot. 2, a także wielu ornamentów na ścianach), które przypominają rozłożoną ludową wycinankę. Inspiracje formalne sztuką ludową dostrzegamy we wcześniejszej i znacznie skromniejszej pracy Józefa Mehoffera: projekcie jednego z fragmentów fryzu dla TPSP w Krakowie, zatytułowanym „Wawel strzegacy ołtarza ojczystego" ${ }^{, 54}$. Twórcze poszukiwania artysty w tym zakresie znalazły swój najpełniejszy wyraz w projekcie polichromii katedry płockiej. Nawiązania stylistyczne do sztuki ludowej występują też w późniejszych dziełach, np. w polichromii sali

${ }^{52}$ T. D o b r o w o $1 \mathrm{~s} \mathrm{k} \mathrm{i,} \mathrm{Nowoczesne} \mathrm{malarstwo} \mathrm{polskie,} \mathrm{t.} \mathrm{2.} \mathrm{Wrocław} \mathrm{1960,} \mathrm{s.} 353$.

${ }^{53}$ Jednym z takich wzorników jest Grammar of Ornament Christophera Dressera, 1856.

${ }^{54}$ Nie zrealizowany projekt "Wawel strzegący ołtarza ojczystego" (znany autorce tylko w wersji szkicowej) ma charakter groteski, opartej na motywie postaci ludzkiej, która „wynurza się" z przestylizowanego kwiata (podobnego do lilii) o promienistym układzie płatków. Motyw ten ma charakter ornamentalny; przypomina ornamenty ludowe $\mathrm{m}$. in. swą symetryczną strukturą i daleko posuniętą stylizacją; również on kojarzy się z ludową wycinanką. 
posiedzeń Izby Przemysłowo-Handlowej w Krakowie (ograniczamy się w tym miejscu jedynie do wsǩkazania przykładów dekoracji malarskich).

O związkach polichromii skarbca $\mathrm{z}$ dziewiętnastowieczną tradycją malarską świadczy dość jeszcze znaczny współczynnik realizmu jej partii figuralnej (zrealizowanej części projektu). Projektując zaś cztery wielkie sceny historyczne Mehoffer niewątpliwie inspirował się malarstwem Jana Matejki. Pozostając pod wpływem wizjonerskiej twórczości swego mistrza, artysta stworzył cykl trójpostaciowych kompozycji z geniuszami; odznaczają się one dramatyzmem, wręcz barokowością formy. Gestykulacją i mimiką geniusze nieodparcie przypominają bohaterów patetycznych scen z płócien wielkiego malarza polskiej historii. Porównajmy np. gesty środkowej postaci z grupy "Geniusze IV" (fot. 3e) i matejkowskiego Wernyhory, czy też gesty centralnej postaci z projektu "Geniusze V" (fot. 3f) i Rejtana. Nie uzasadniona natomiast jest opinia, że wyobrażenia aniolów $\mathrm{z}$ dekoracji malarskiej skarbca wzorowane sa na aniołach matejkowskich z polichromii prezbiterium kościoła Mariackiego ${ }^{55}$. Anioły z kompozycji Mehoffera różnią się znacznie w ogólnym wyrazie od tych malowanych przez Matejkę; zupełnie inna zresztą jest ich koncepcja ikonograficzna. Należy natomiast podkreślić, iż polichromia kościoła Mariackiego, dzieło prekursorskie i o szerokiej skali oddziaływania, wywarła decydujący wpływ na szerzej rozumianą stylistykę dekoracji malarskich Mehoffera.

Jak stwierdzono powyżej, w polichromii skarbca pojawia się wiele elementów przejętych z malarstwa minionego stulecia. Wszelkie jednak środki wyrazu tejże polichromii znajdują uzasadnienie w jej funkcjach dekoracyjnych, o kształcie dzieła rozstrzyga kryterium formalne. Tak więc, dekoracja malarska skarbca jest materialnym wyrazem poglądów Mehoffera, które zawarł w rozprawie $U w a-$ gi o sztuce i jej stosunku do natury ${ }^{56}$, opublikowanej w 1897; młody artysta krytykował występującą w malarstwie dziewiętnastowiecznym tendencje do „bezmyślnego naśladowania natury”, pisał, że ,sztuka zawsze przetwarzała i przetwarzać będzie naturę, doszukując się w niej stylu". Słowa te odzwierciedlają idee „Sztuki ok. 1900".

Analiza ikonograficzna polichromii skarbca katedralnego ujawnia jej silne jeszcze związki ze sztuką XIX wieku. Mehoffer nawiązał do tradycji malarskiej ubiegłego stulecia przede wszystkim w projekcie wielkich kompozycji historycznych. Zamysł ten stanowi kontynuację wcześniejszych zainteresowań artysty; uwidacznia się to szczególnie w koncepcji malowidła na wschodnią ścianę skarbca: rozwija ono idee, które pojawiły się w projektach polichromii triforiów mariackich i kościoła Franciszkanów ${ }^{37}$. Objaśnienia Mehoffera na wzmiankowa-

${ }^{55}$ Jak to czyni M. S a m 1 i c k i, w opracowaniu Józef Mehoffer, Kraków 1912, s. 4, [Wspótczesne malarstwo polskie, z. 4.].

${ }^{56} \mathrm{~J}$. M e h of fe r, Uwagi o sztuce i jej stosunku do natury, Kraków 1897 (nakładem autora). Artykuł drukowany w "Przeglądzie Polskim”, 31: 1897, t. 124, s. 26, 19-20.

${ }^{57}$ Tematem planowanej polichromii do triforiów mariackich miała być „,Matka Boża, Królowa Polski, unosząca się na tle ołtarza procesyjnego, przed którą klęczą fundatorowie kościoła". Po bokach Mehoffer zamierzał przedstawić świętych polskich, w dalszej zaś partii dekoracji „procesyjnie zbliżającą się Polskę współczesną, na tle wiosennego krajobrazu" (K o z i c k i, Józef Mehoffer; 
nym, drobnym szkicu (zob. przypis 43 i fot. 11) świadcza, iż w dekoracji skarbca zamierzał pierwotnie wyobrazić średniowiecznych świętych; kompozycja ta nawiązywałaby przez swój temat do „pochodów” polskich świętych (lub wybitnych średniowiecznych postaci) z projektu polichromii triforiów, a przede wszystkim z projektu polichromii kościoła Franciszkanów. W dwóch ostatnich dziełach, jak również w projekcie polichromii skarbca „centrum ideowym” miało być wyobrażenie Matki Bożej („Matki Bożej Królowej Polski” lub „Bogarodzicy”) wśród adorujących ją polskich świętych lub wybitnych postaci z polskich dziejów. Genezie tego tematu można by niewątpliwie poświęcić odrębne studium. W malarstwie dziewiętnastowiecznym rozwinał się on i wzbogacił. Jego wersja mehofferowska mieści się w klimacie polskiego historyzmu, mającego specyficzny kontekst polityczny i kulturowy. Dziełem, który mógł być dla artysty bezpośrednim źródłem inspiracji (w tym miejscu bowiem wskażemy na analogie najbardziej uchwytne) jest tryptyk „Królowa Korony Polskiej” pędzla Jana Matejki, z lat 1887-1888 ${ }^{58}$. W jego środkowej części, na tle wnętrza katedry wawelskiej, Matejko przedstawił Matkę Bożą z Dzieciątkiem, która zasiada na tronie niesionym w uroczystej procesji. Otaczaja ją po bokach święci polscy ${ }^{59}$. Dokładniejsza analiza przedstawień figuralnych na obrazie Matejki i projektach Mehoffera (znanych niekiedy tylko z opisów) pozwala dostrzec wyraźną zbieżność ich tematów: w mehofferowskich pochodach świętych pojawia się wiele postaci wyobrażonych w niniejszym tryptyku (por. przypisy: 43, 57, 59). Tak więc, ikonograficzne związki z malarstwem historyzmu, szczególnie z twórczością Matejki, są istotną cechą dzieła Mehoffera. Przykładem współczesnej Mehofferowi adaptacji tematu Matki Bożej wśród świętych polskich są dwa malowidła ścienne Włodzimierza Tetmajera: jedno z nich stanowi fragment polichromii kaplicy Św. Trójcy w katedrze na Wawelu (1900-1903), drugie zdobi kaplicę Matki Bożej Pocieszenia

szkicowy projekt prezentowany na wystawie Opus Magnum (zob. przypis 2) jest zbliżony tematycznie do projektu opisanego przez Kozickiego).

W polichromii prezbiterium kościoła Franciszkanów artysta pragnął wprowadzić dwa równoległe fryzy z postaciami z pierwszych wieków historii Polski: na ścianie południowej zamierzał wyobrazić „święte polskie" (m. in. Kingę, Jadwige Trzebnicka, bł. Bronisławę i Salomeę), a na ścianie północnej - wybitnych władców piastowskich (m.in. Bolesława Wstydliwego, Henryka Brodatego, Henryka Pobożnego, Leszka Białego, Bolesława Chrobrego); centralną kompozycją byłby wizerunek Bogarodzicy, otoczonej chórem śpiewających rycerzy (malowidlo to prawdopodobnie miałoby przedstawiać bitwę legnicką).

Wspomnijmy też projekt polichromii kaplicy królowej Zofii, złożony z czterech scen o tematyce historycznej (poświęconych fundatorce kaplicy): analogiczny do nich charakter miały kompozycje z projektu polichromii południowej ściany skarbca.

${ }^{58}$ Tryptyk J. Matejki „Królowa Korony Polskiej”. Część środkowa: olej, deska; 79 x 62 cm; sygn.: „r. p. 1887 J. Matejko”. Dwa skrzydła boczne: olej, pł; 78 x $26 \mathrm{~cm}$; lewe i prawe - sygn.: „J. M. r. p. 1888”. Pierwotnie tryptyk był wł. rodziny hr. Tarnowskich, zrabowany podczas II wojny światowej, obecnie wł. pryw. - M. P r z e m e c k a - Z i e 1 i ń s k a, Malarstwo religijne Jana Matejki, Kraków 1994, s. 22, 34.

${ }^{59}$ M.in.: Jan Kanty, Stanisław Kostka, Jadwiga, bł. Bronisława i Salomea, św. Wojciech, Stanisław Szczepanowski. Na lewym skrzydle tryptyku wyobrażono "obrońców chrześcijaństwa": księcia Henryka Pobożnego, króla Władysława Warneńczyka, hetmana Stanisława Żółkiewskiego. $\mathrm{Na}$ prawym - prześladowanych za wiarę unitów podlaskich (1868-1872). 
w kościele Św. Mikołaja w Kaliszu (ok. 1903) ${ }^{60}$; podobieństwo ikonograficzne dekoracji malarskich Mehoffera i Tetmajera ma jednak charakter ogólny (dodajmy, że w polichromiach Tetmajera temat Matki Bożej wsród polskich świętych został rozszerzony o motyw alegorii umarłej Polski).

Malowidła $\mathrm{z}$ archaniołami i aniołami reprezentuja już młodopolską koncepcję ikonograficzną - Mehoffer wprowadził w nich na szerszą skalę elementy ludowe, zapożyczone z polskiego folkloru. „Folkloryzacja” motywów to jeden z najistotniejszych symptomów sztuki Młodej Polski. Prekursorem tej tendencji był Stanisław Wyspiański, który w projekcie witraża „Polonia” dla katedry lwowskiej, z lat 1892-1894, umieścił wizerunek „ludowej Madonny"; w 1896 zaprojektował karton (zrealizowany) z postacią Madonny z Dzieciątkiem do polichromii kościoła Franciszkanów w Krakowie, na którym Maria to czule tuląca swe niemowlę młoda kobieta w stylizowanym, ludowym stroju; tło tej kompozycji stanowią barwne, dorodne kwiaty georginii. W sztuce Józefa Mehoffera ludowe motywy ikonograficzne pojawiaja się ok. roku 1900. W projekcie „Natura i Sztuka" (fragmencie projektu fryzu na gmach TPSP w Krakowie) Naturę przedstawił jako wiejską dziewczynę o słowiańskim typie urody. Takie, nowe środki wyrazu mogły w jego sztuce wykształcić się niezależnie, równolegle do „nurtu ludowego" twórczości Wyspiańskiego. W każdym razie Mehoffer, obok Wyspiańskiego, jest wspóltwórca opartej na motywach symboliczno-ludowych ikonografii młodopolskiej. Zainteresowanie „ludowością" znalazło w jego twórczości w pełni dojrzały wyraz w polichromii skarbca katedralnego - w wyobrażeniach aniołów i archaniołów. W polichromii tej uzewnętrzniło się również właściwe twórcom „Sztuki ok. 1900” - zamiłowanie artysty do ornamentyki roślinnej, która spełnia ważne funkcje symboliczne.

W mehofferowskiej dekoracji skarbca z wątkami i tematami zaczerpniętymi z malarstwa XIX wieku współistnieją więc nowe motywy i rozwiązania ikonograficzne, przesądzające o przełomowym charakterze dzieła. Należy równocześnie podkreślić, iż źródła jego koncepcji ideowej tkwią w polskiej tradycji romantycznej, w której niezwykle silnie były zakorzenione idee mesjanistyczne.

${ }^{60}$ J. A. Now obilski, Sakralne malarstwo ścienne Wtodzimierza Tetmajera, Kraków 1994 , s. $29,80$.

${ }^{61}$ Projekt „Natura i Sztuka”, obecnie depozyt w MNKr, N.D. 8673. Akw. i pozłota, pap. naklejony na pł.; $130 \times 360 \mathrm{~cm}$. Sygn. „Mehoffer/1901” (karton opracowany wg wcześniejszych projektów konkursowych). 


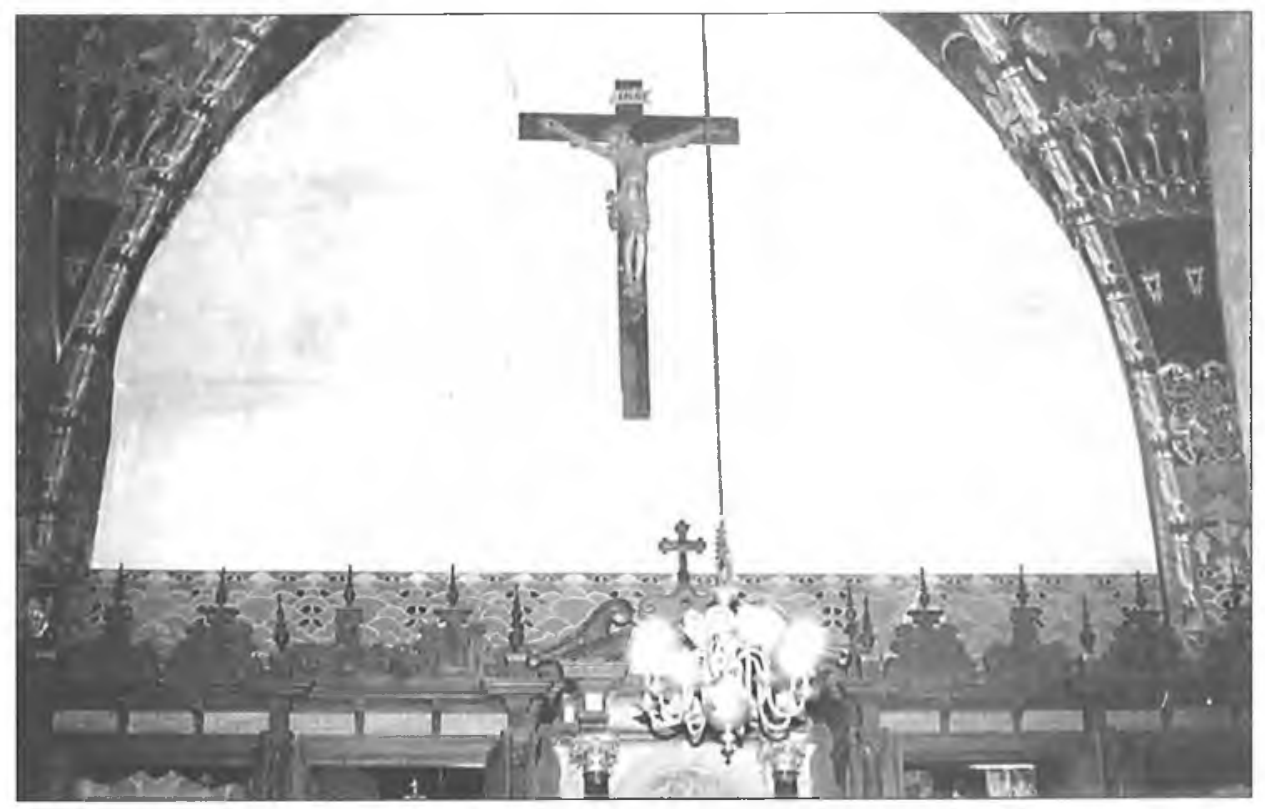

1a. Józef Mehoffer, polichromia skarbca katedry na Wawelu, widok ściany wschodniej skarbca (Fot. Z. Janusz).

1b. Józef Mehoffer, polichromia skarbca katedry na Wawelu, ściana potudniowa skarbca (Fot. Z. Janusz).

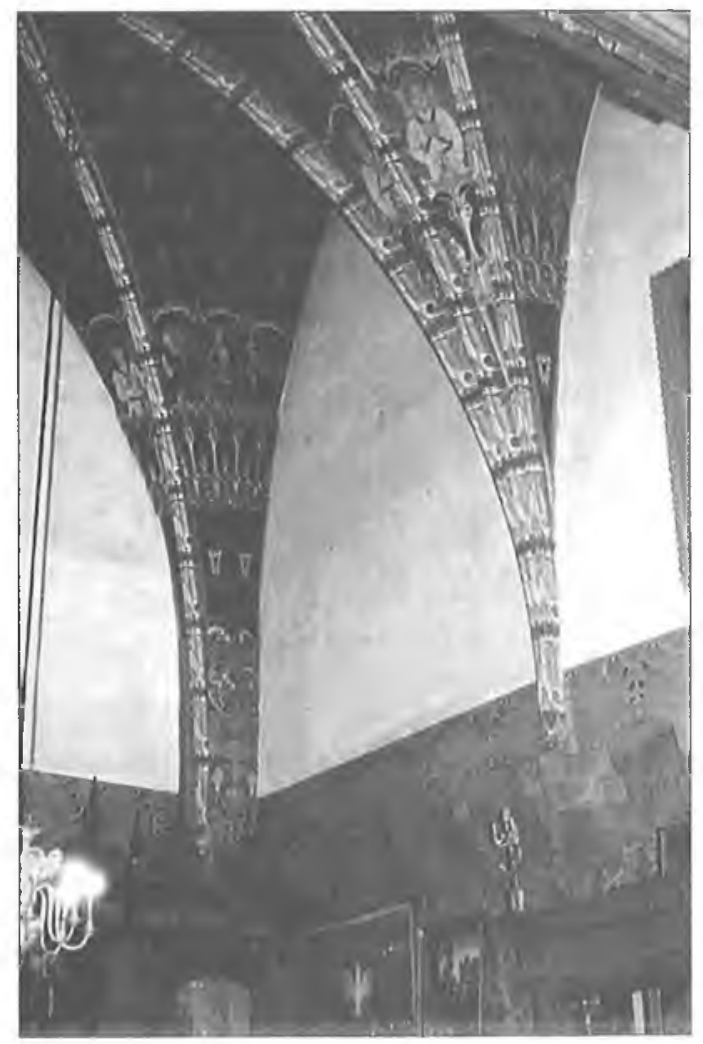




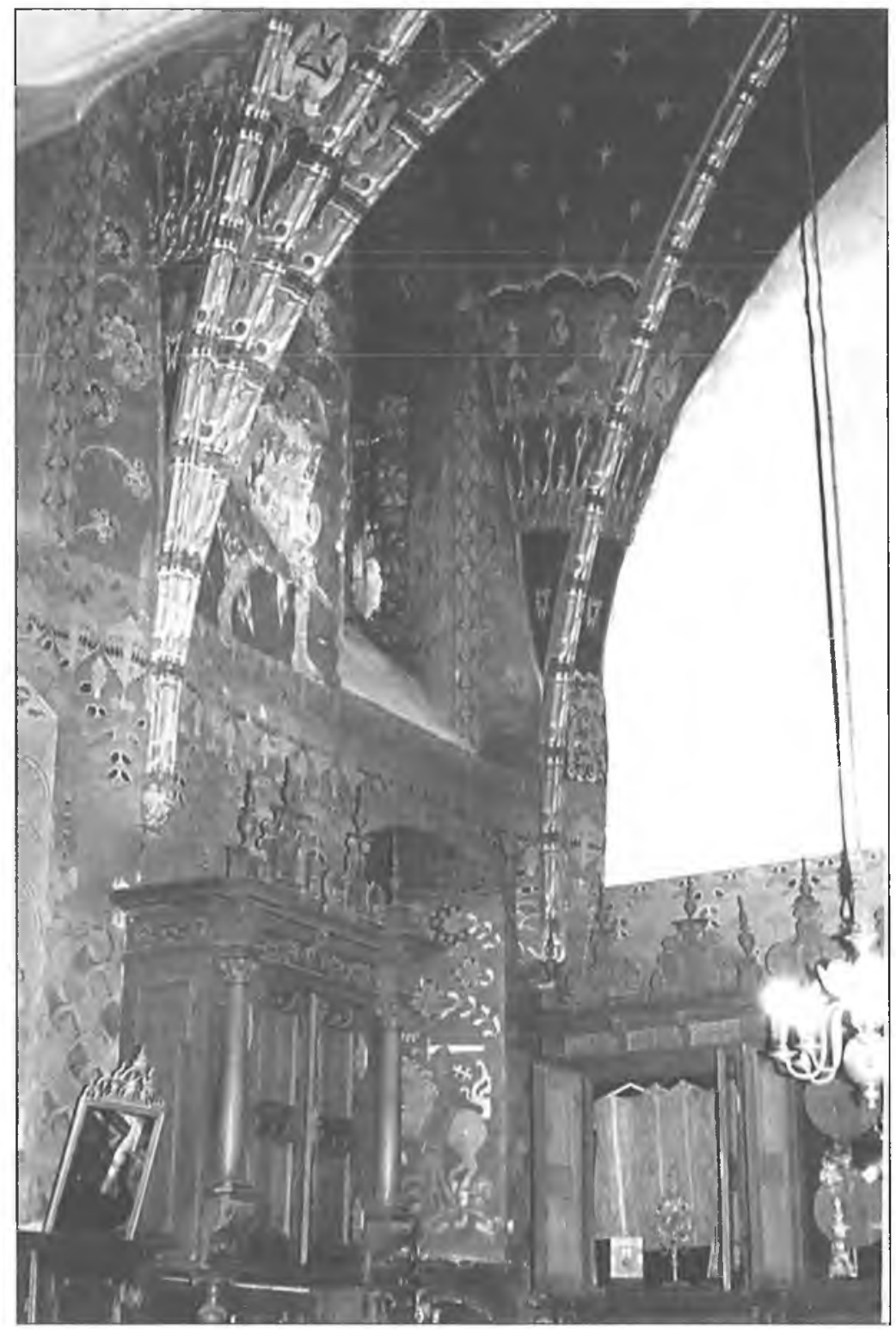

1c. Józef Mehoffer, polichromia skarbca katedry na Wawelu, ściana pótnocna skarbca (Fot. Z. Janusz). 


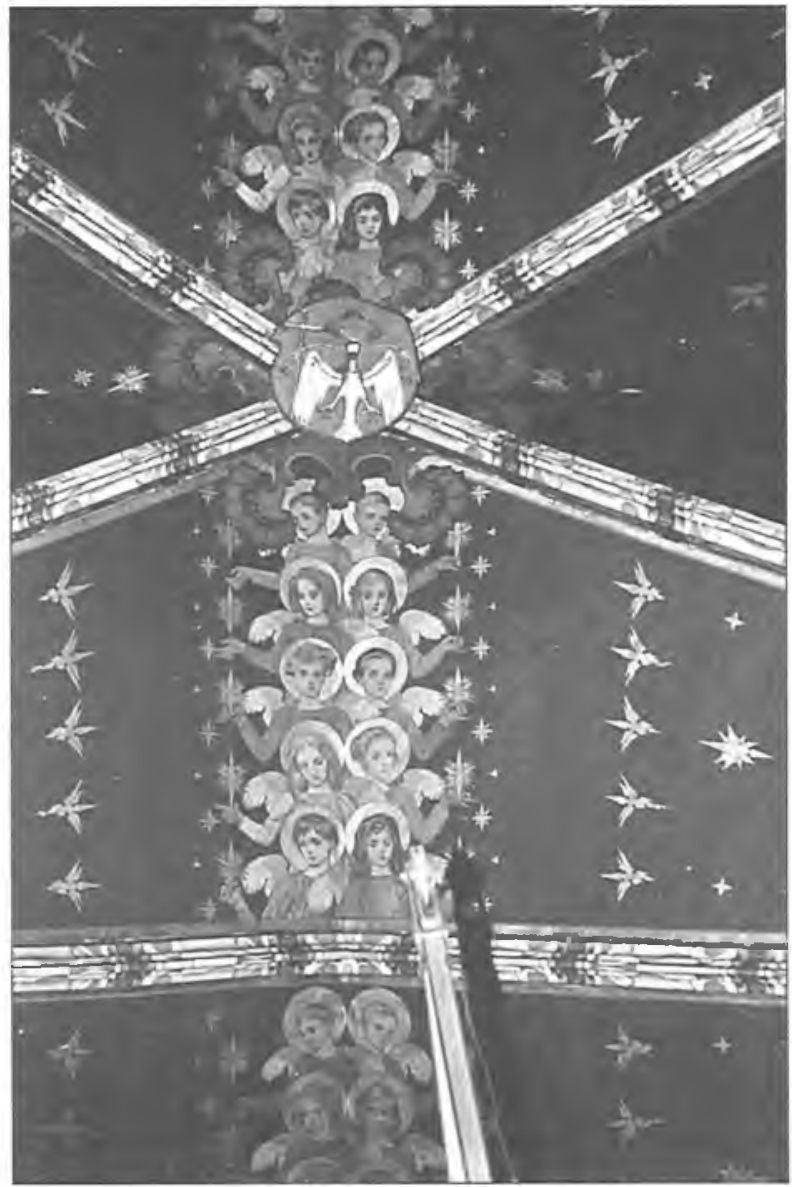

2. Józef Mehoffer, polichromia sklepienia skarbca katedry na Wawelu (Fot. Z. Janusz). 


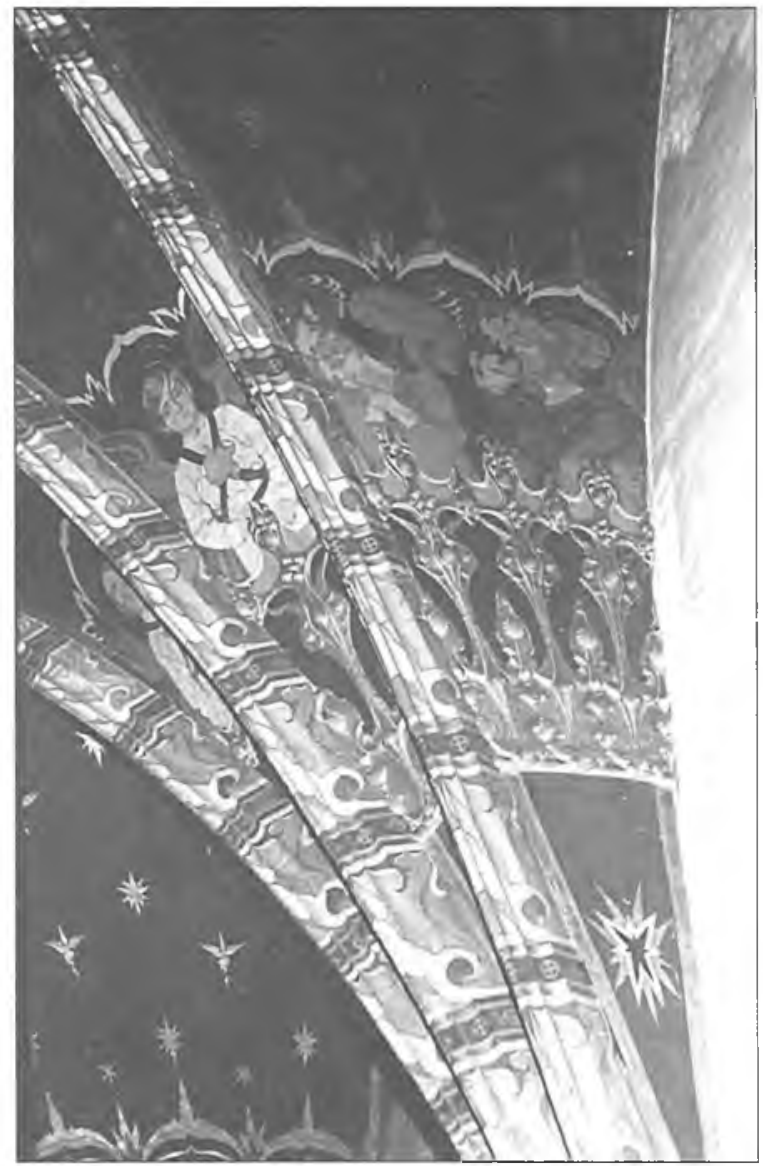

3. Józef Mehoffer, polichromia skarbca katedry na Wawelu, dekoracja w dolnych partiach sklepienia (Fot.

Z. Janusz). 


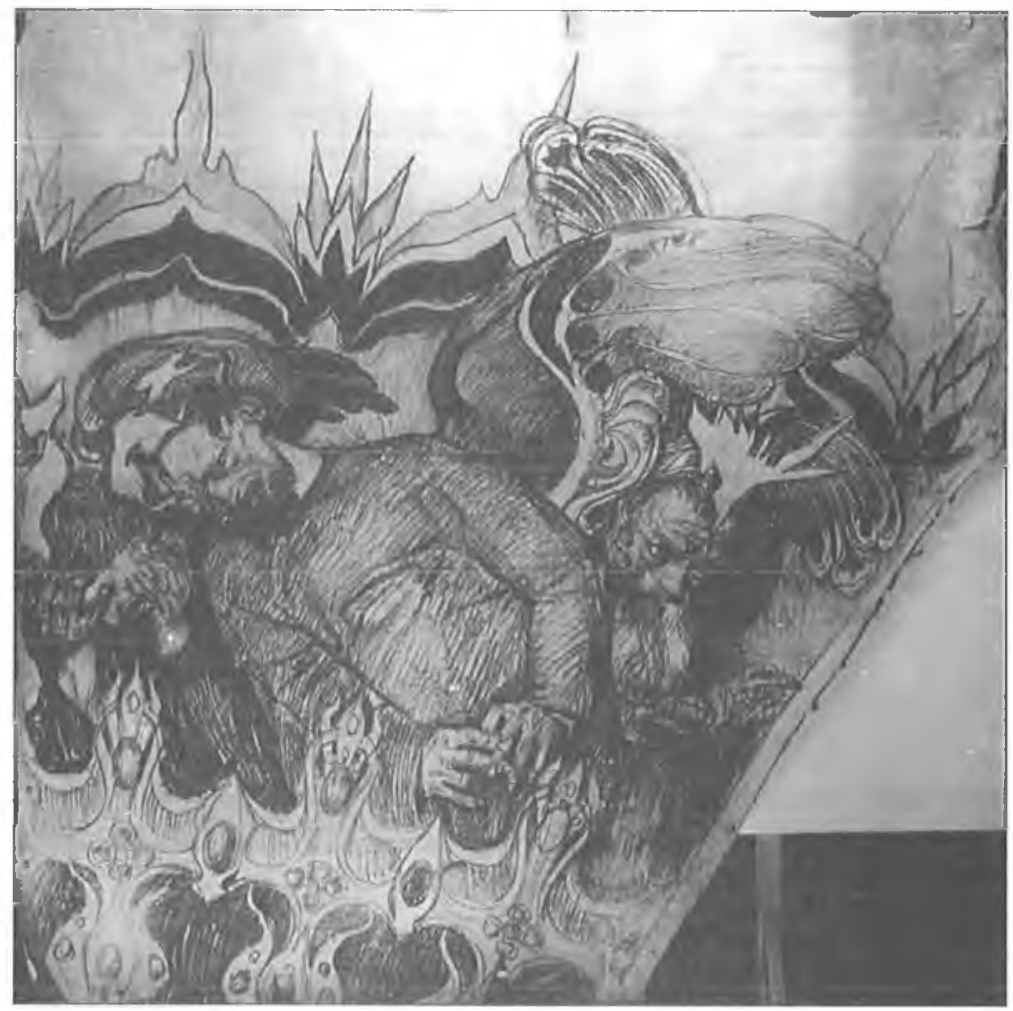

3a. Józef Mehoffer, „Geniusze I”, projekt do polichromii skarbca katedry na Wavelu. Dep. w Muz. Maz. w Płocku (Fot. W. Dyśkiewicz).

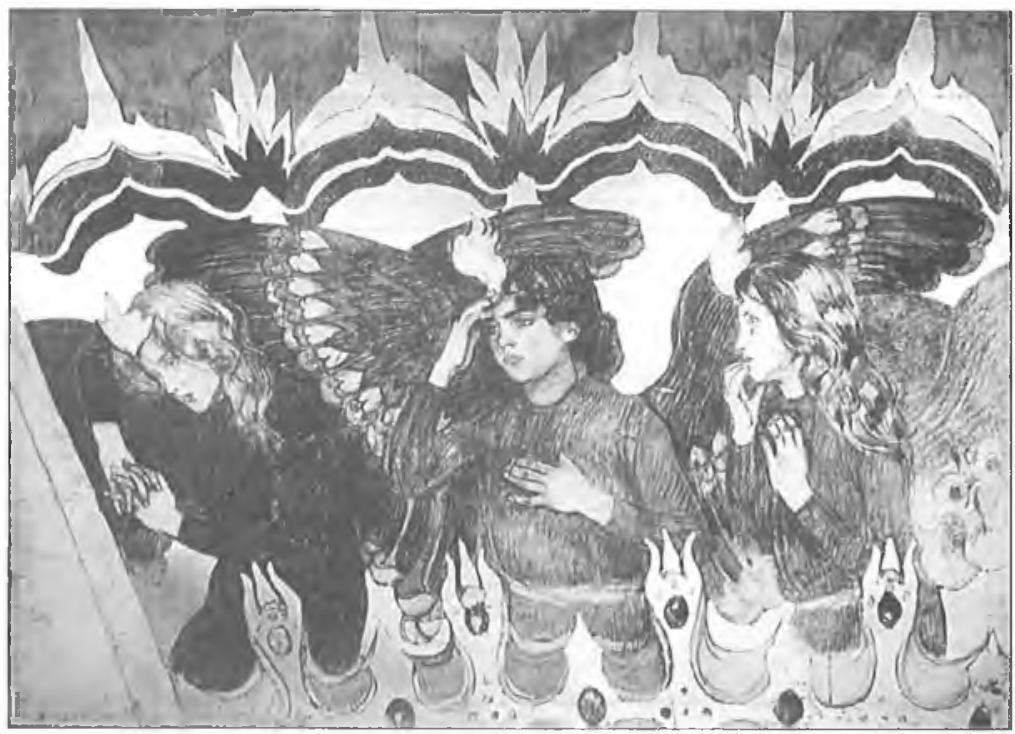

3b. Józef Mehoffer, „Geniusze II" (1), projekt do polichromii skarbca katedry na Wawelu. Muz. Maz. w Płocku. (Fot. W. Dyśkiewicz). 


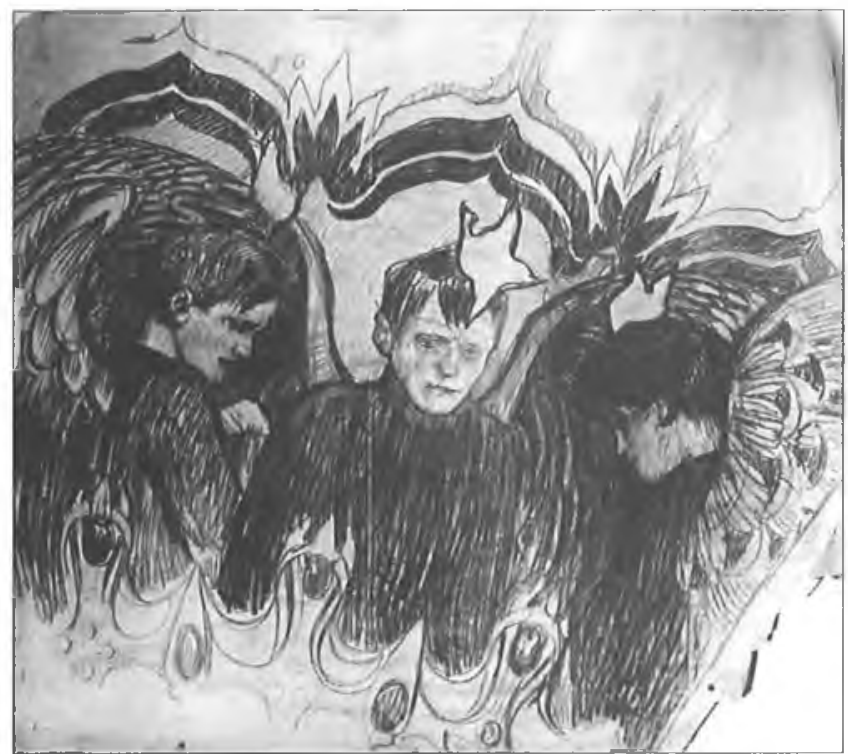

3c. Józef Mehoffer, „Geniusze II” (2), projekt do polichromii skarbca katedry na Wawelu. Dep. w Muz. Maz. w Plocku (Fot. W. Dyśkiewicz)

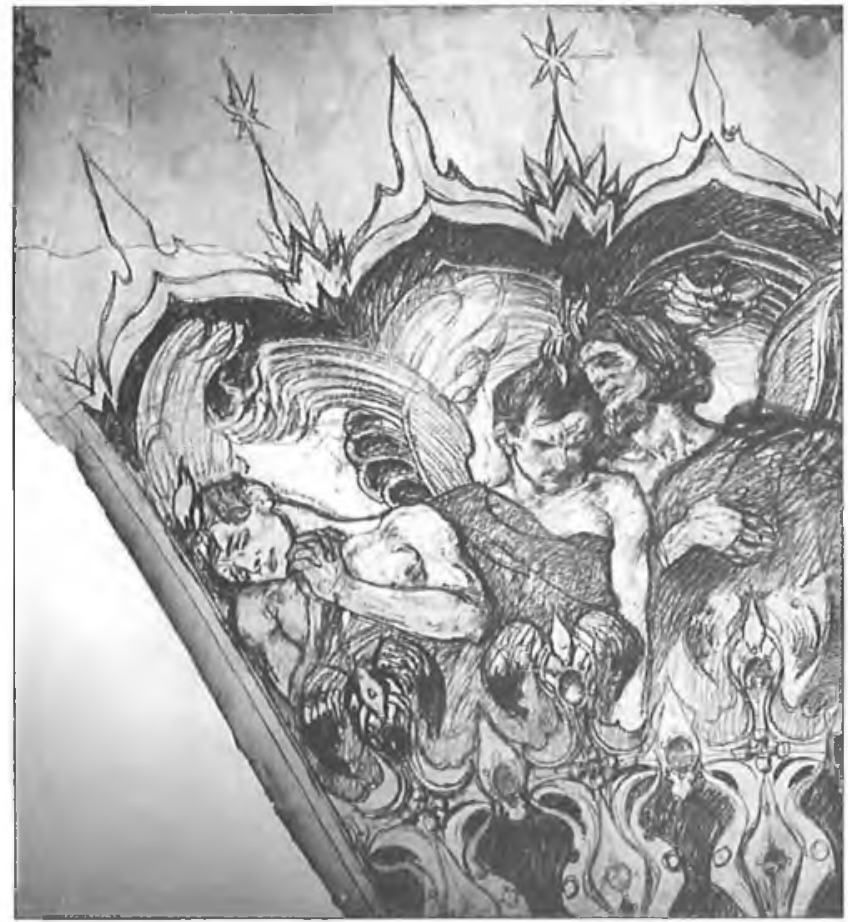

3d. Józef Mehoffer, „Geniusze III”, projekt do polichromii skarbca katedry na Wawelu. Dep. w Muz. Maz. w Plocku (Fot. W. Dyśkiewicz). 


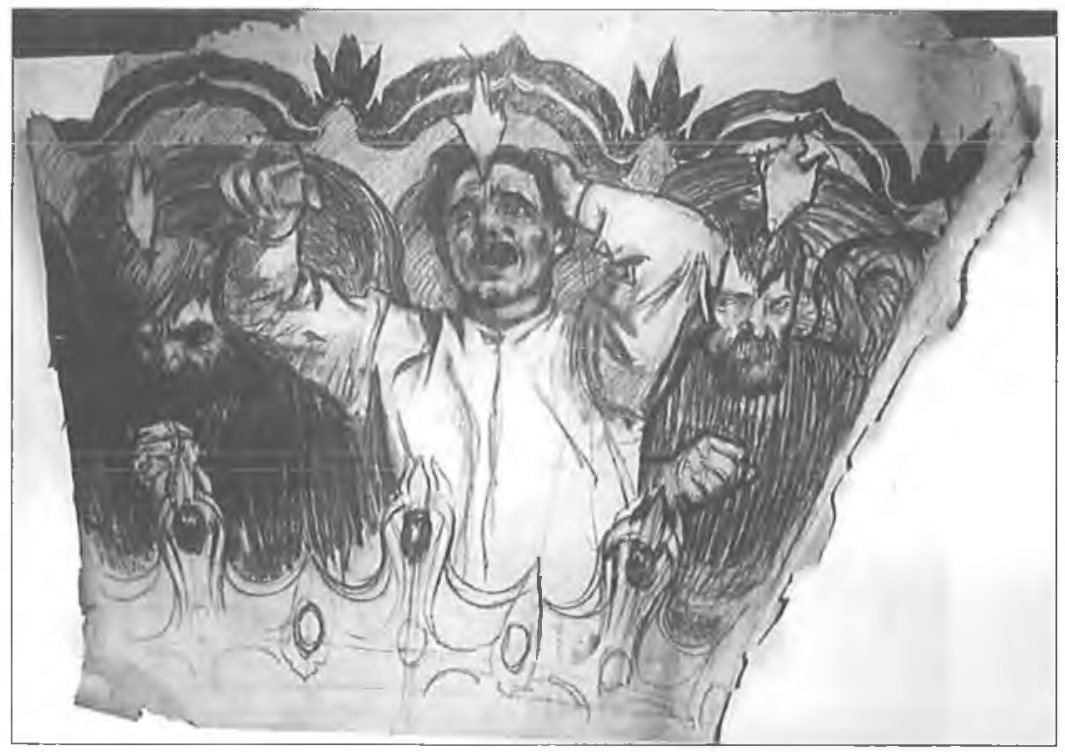

3e. Józef Mehoffer, „Geniusze IV”, projekt do polichromii skarbca katedry na Wawelu. Dep. w Muz. Maz. w Płocku (Fot. W. Dyśkiewicz).

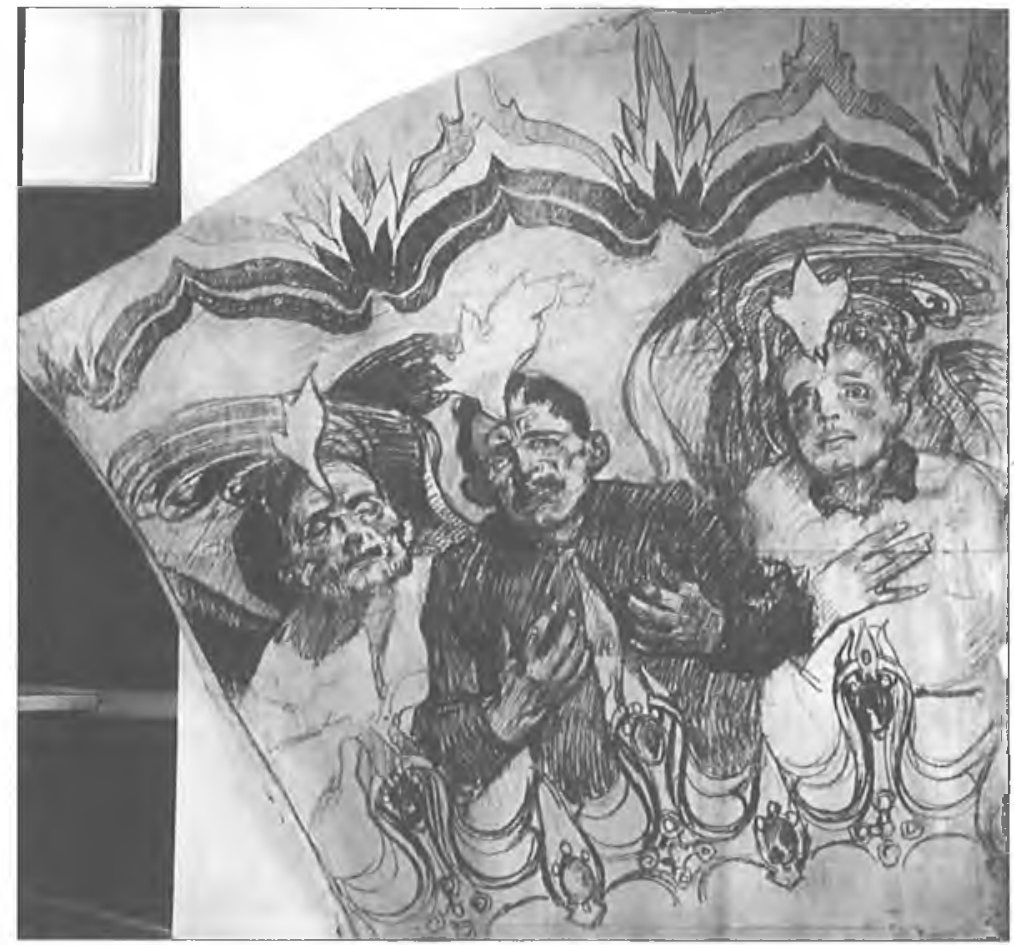

3f. Iózef Mehoffer, „Geniusze V”, projekt do polichromii skarbca katedry na Wawelu. Dep. w Muz. Maz. w Płocku (Fot. W. Dyśkiewicz). 


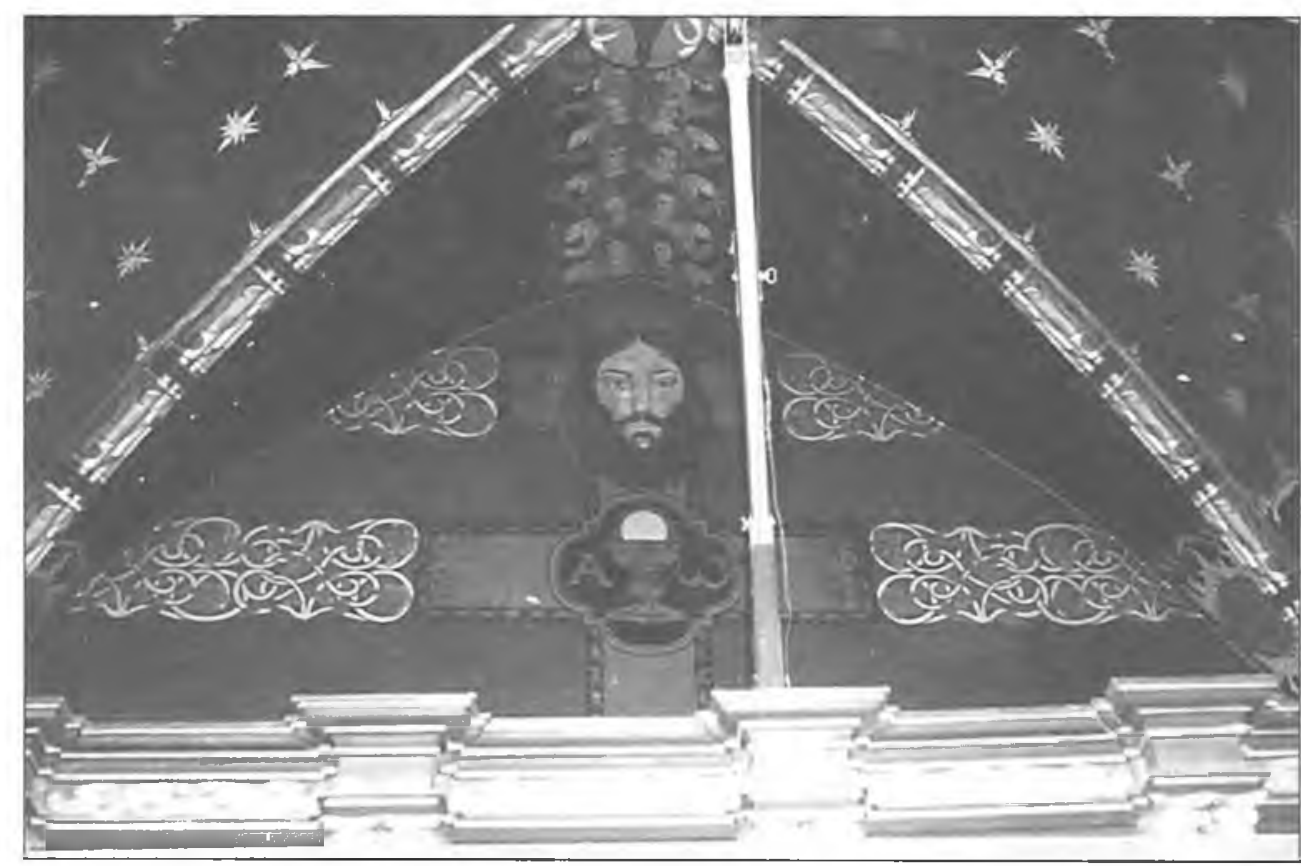

4. Józef Mehoffer, polichromia skarbca katedry na Wawelu, ściana zachodnia (Fot. Z. Janusz). 


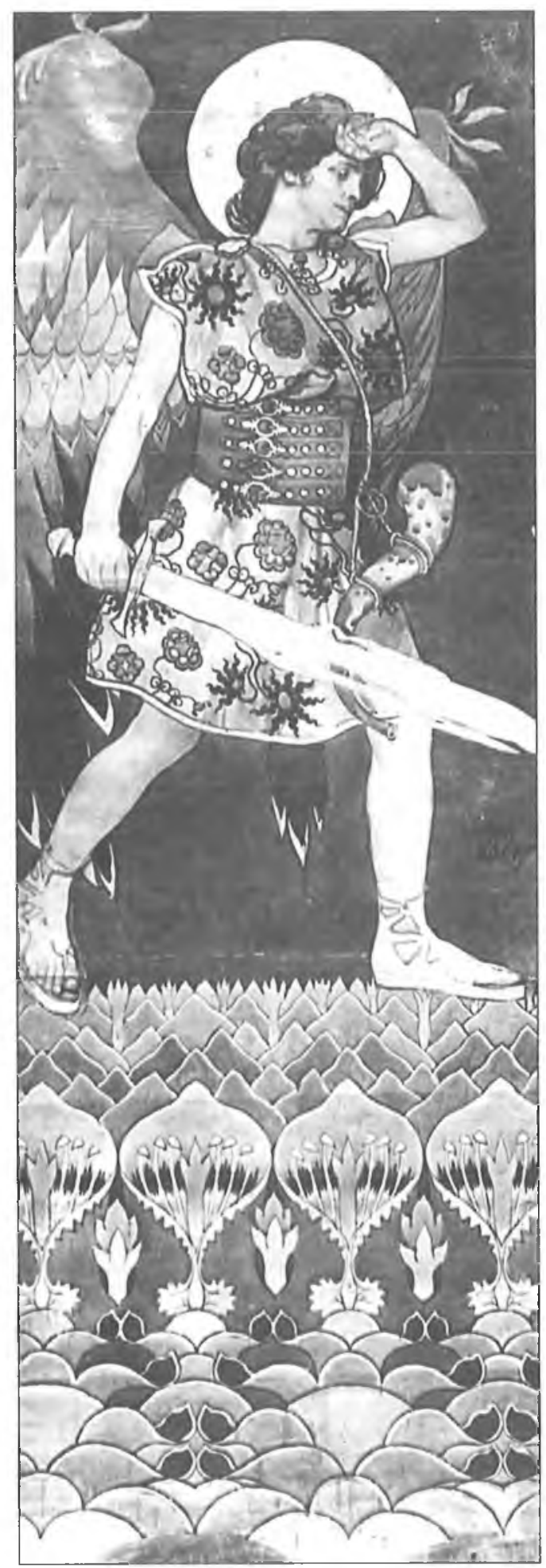

5a. Józef Mehoffer, „Archaniot Michat”, projekt do polichromii skarbca katedry na Wawelu. MNP (Fot. L. Perz, F. Maćkowiak). 


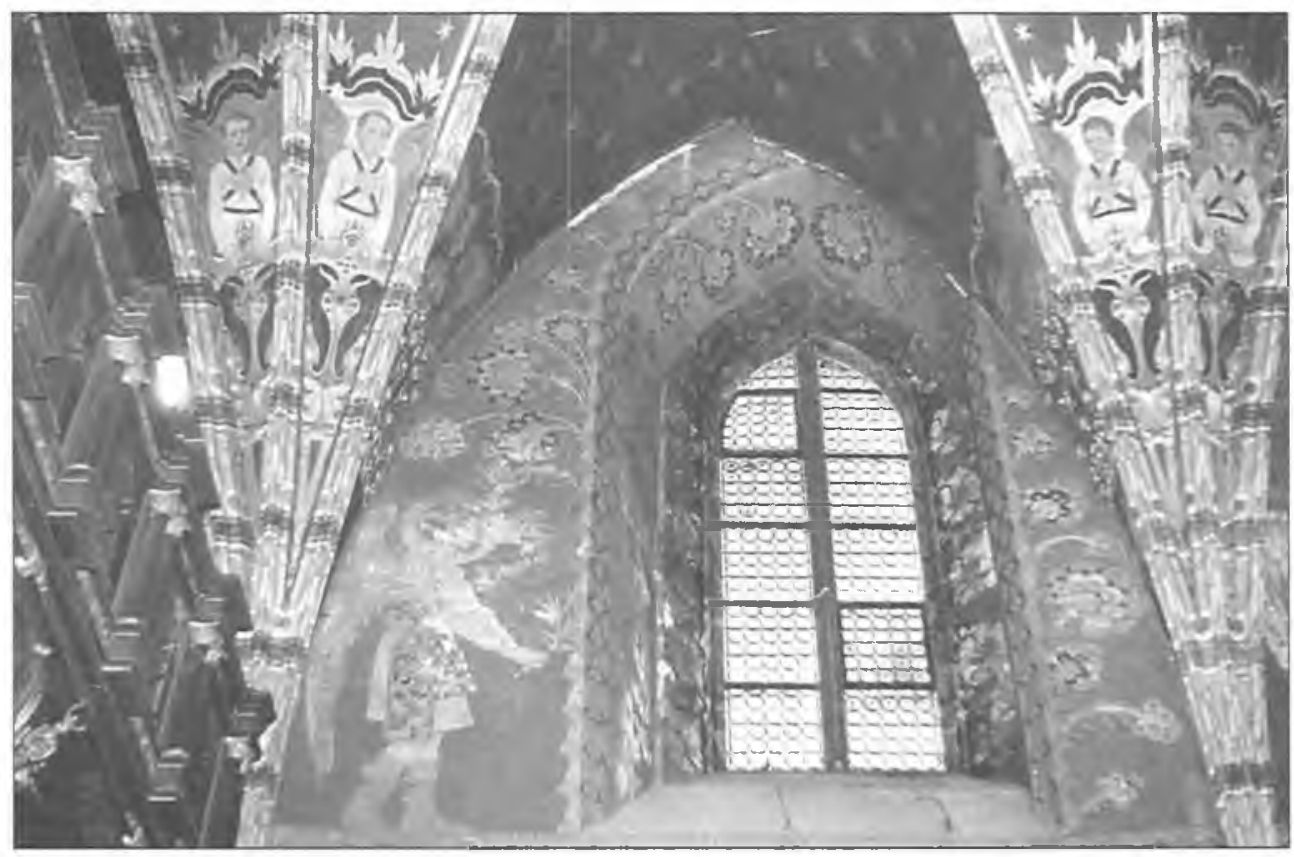

5b. Józef Mehoffer, „Archantoi Gabriel”, fragment polichromii ściany pótnocnej skarbca katedry na Wawelu (Fot. Z. Janusz). 


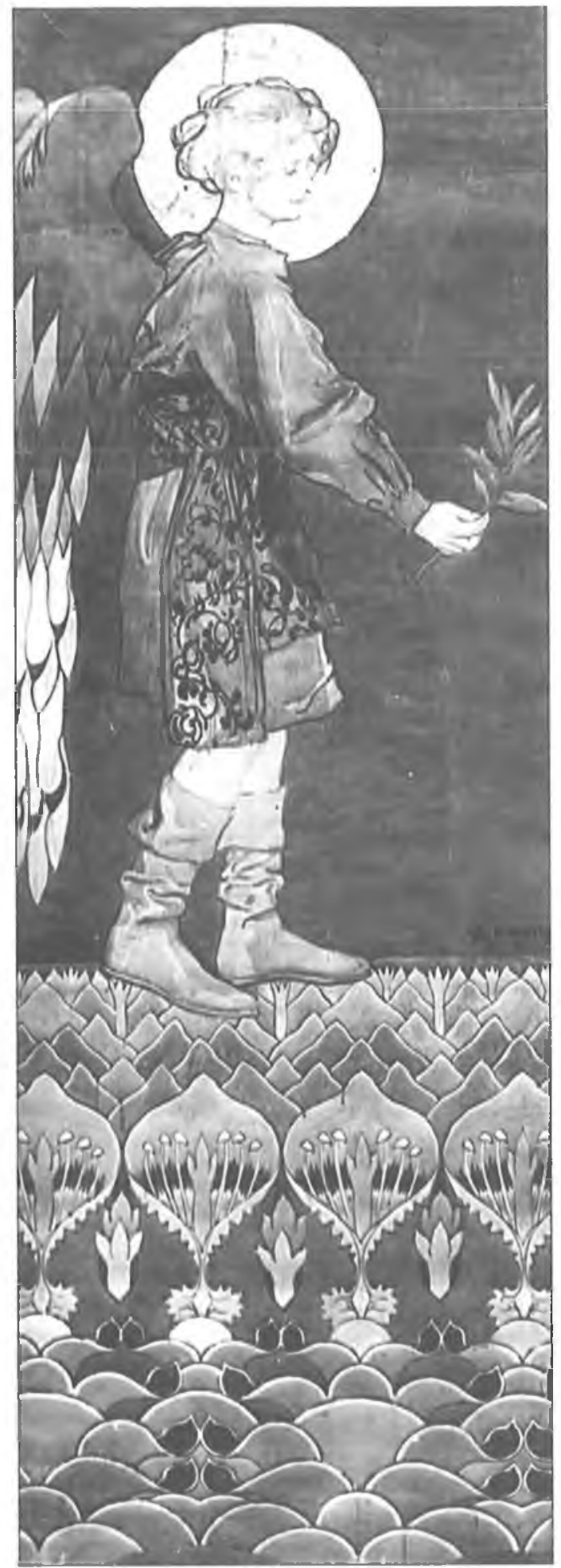

5c. Józef Mehoffer, „Archaniot Gabriel”, projekt do polichromii skarbca katedry na Wawelu. MNP (Fot. L. Perz. F. Maćkowiak). 


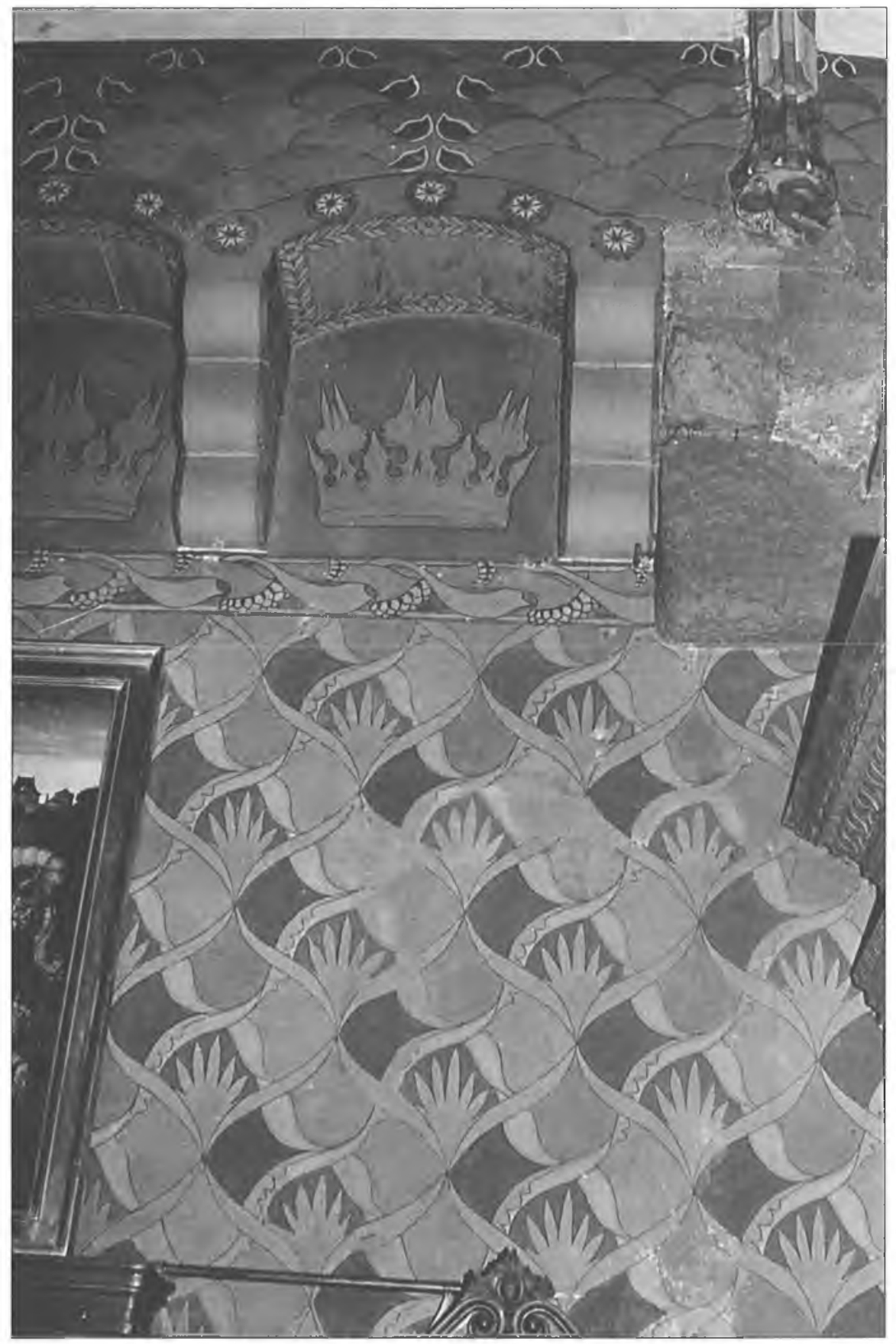

6. Józef Mehoffer, polichromia skarbca katedry na Wawelu, fragment dekoracji ornamentalnej ściany poludniowej (Fot. Z. Janusz). 


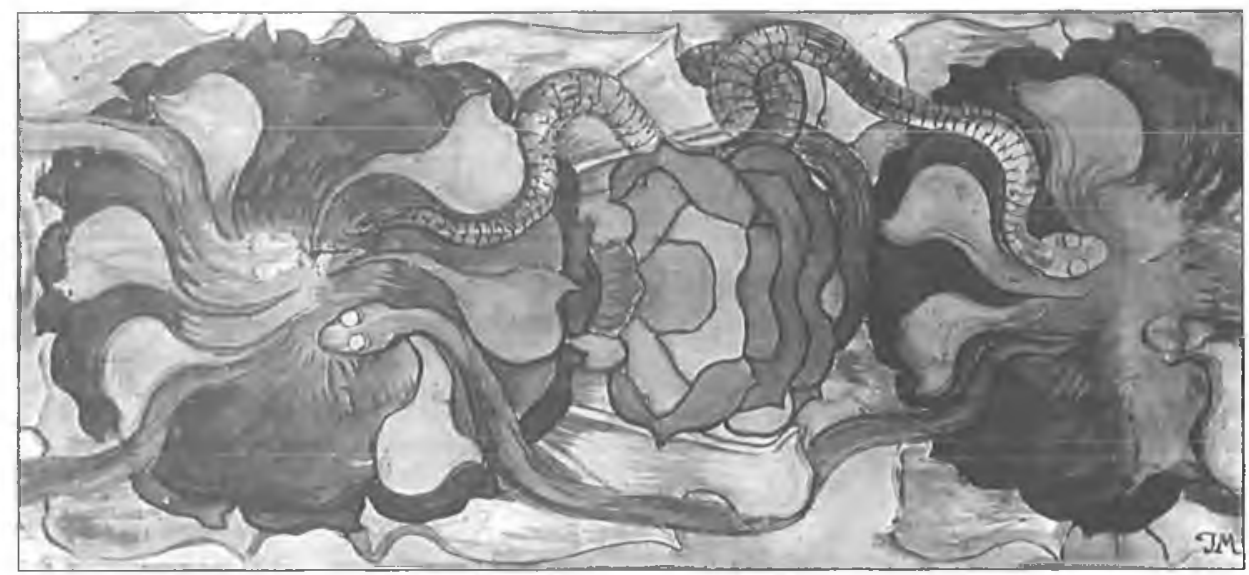

7. Józef Mehoffer, „Węże wśród róż”, projekt do polichromii skarbca katedry na Wawelu. Dep. w MNKr. (Fot. Z. Janusz).

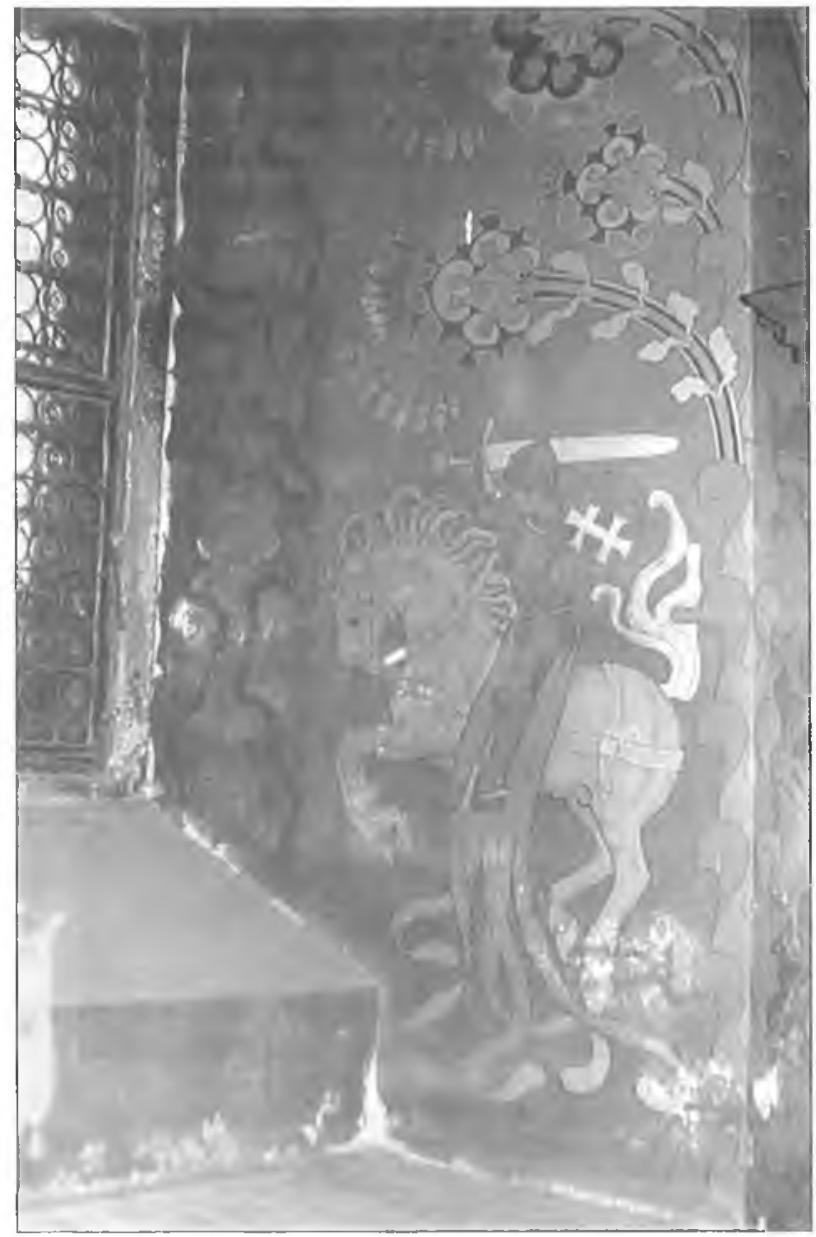

8a. Józef Mehoffer, polichromia skarbca katedry na Wawelu, fragment dekoracji glifow z herbem "Pogoni" $i$ motyw'em ornamentalnym „Węże wśród róż" (Fot. Z. Janusz). 


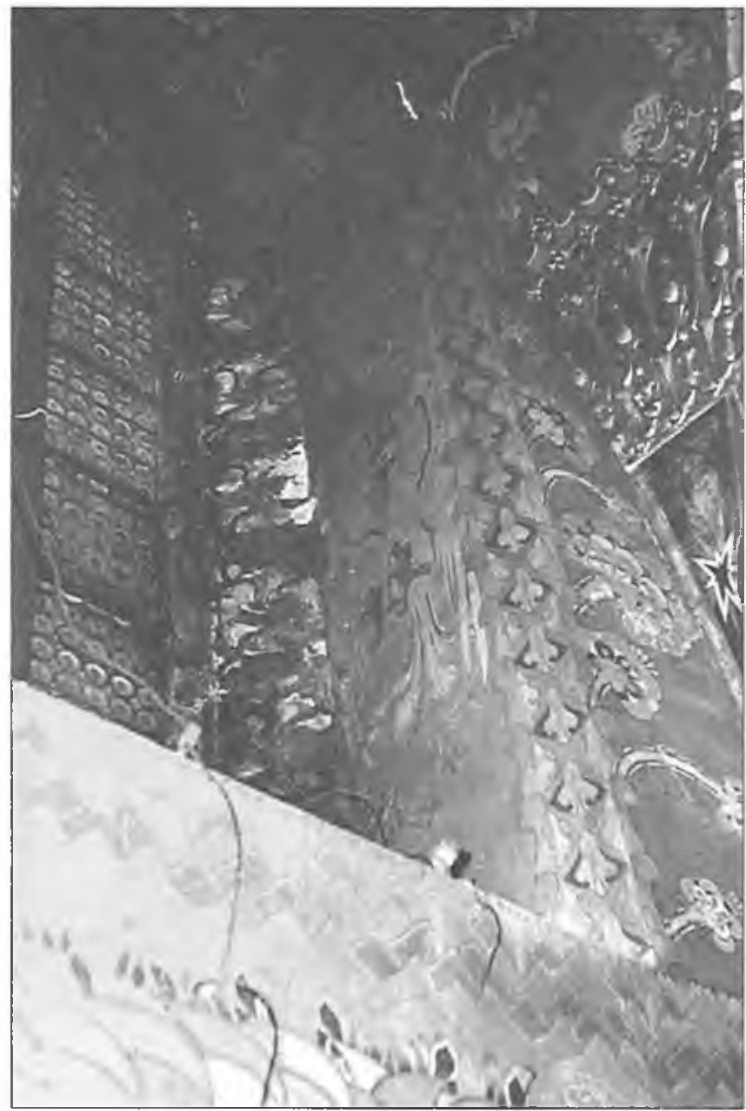

8b. Józef Mehoffer, polichromia skarbca katedry na Wawelu, fragment dekoracji glifów z Ortem jagiellońskim i motywem ornamentalnym ,Węze wśród róż" (Fot. Z. Janusz). 


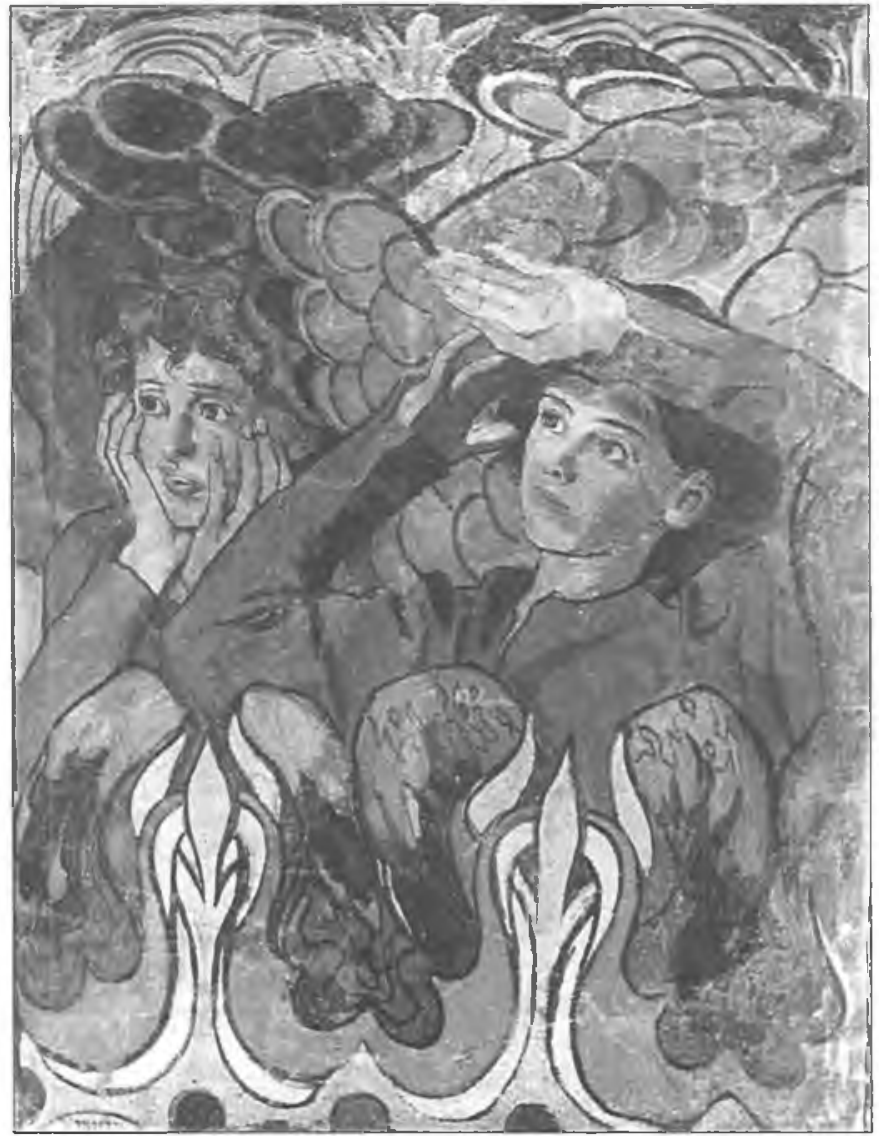

9. Józef Mehoffer, „Zachwycone Anioty”, projekt do polichromii skarbca katedry na Wawelu. Dep. w MNKr. (Fot. Pracownia Fotograficzna MNKr.). 

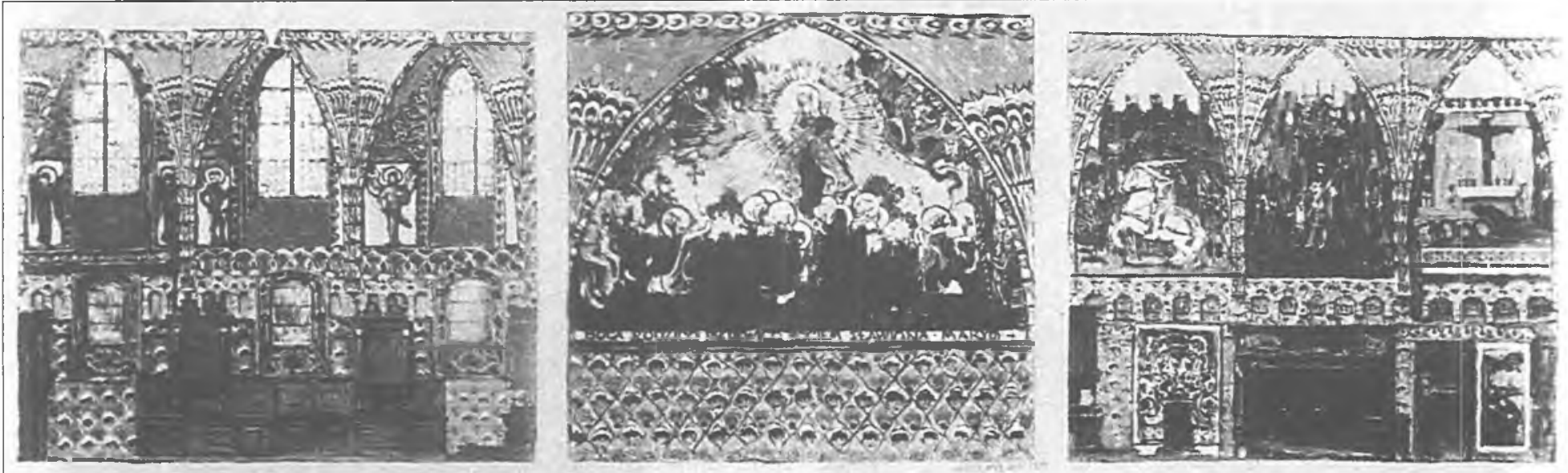

10. Józef Mehoffer, projekt dekoracji figuralnej skarbca katedralnego (nie zrealizowany). Odbitka fotograficzna na podstawie fotografii Kriegera, Muzeum Historyczne m. Krakowa. 


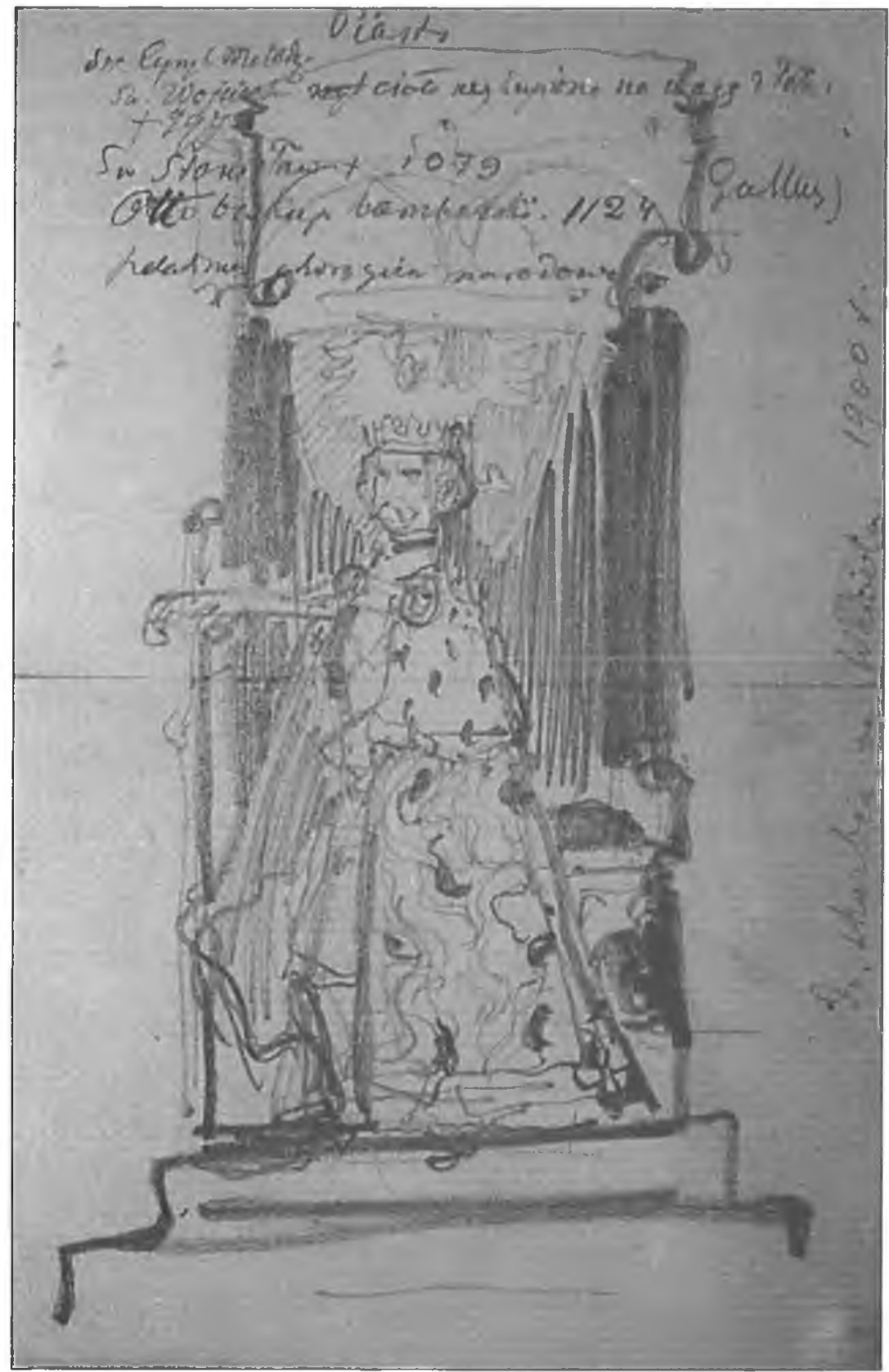

11. Józef Mehoffer, szkic rysunkowy kompozy'cji "Piast” do polichromii skarbca katedry' na Wawelu. Zb. pryw. (Fot. Z. Janusz). 